Portland State University

PDXScholar

\title{
A Correlational Study of Cognitive Style Measured by the Myers-Briggs Type Indicator and the Witkin Group Embedded Figure
}

Leith Wood Muessle

Portland State University

Follow this and additional works at: https://pdxscholar.library.pdx.edu/open_access_etds

Part of the Cognitive Psychology Commons, and the Personality and Social Contexts Commons Let us know how access to this document benefits you.

\section{Recommended Citation}

Muessle, Leith Wood, "A Correlational Study of Cognitive Style Measured by the Myers-Briggs Type Indicator and the Witkin Group Embedded Figure" (1989). Dissertations and Theses. Paper 3900.

https://doi.org/10.15760/etd.5784

This Thesis is brought to you for free and open access. It has been accepted for inclusion in Dissertations and Theses by an authorized administrator of PDXScholar. Please contact us if we can make this document more accessible: pdxscholar@pdx.edu. 
AN ABSTRACT OF THE THESIS OF Leith WaAd Muesele for the Master of Science in Paycholagy presented July 18.1989.

Title: A Carreletional Study af Cognitive Style Measured by the Myere-Brigge Type Indicator and the Witkin Graup Embedded Figures Test.

APPRQVEN BY THE MEMBERS OF THE THESIS COMMITTEE:

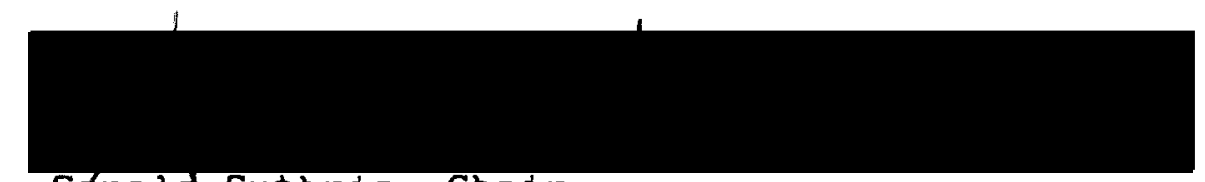

Gerald Guthrie, Chair
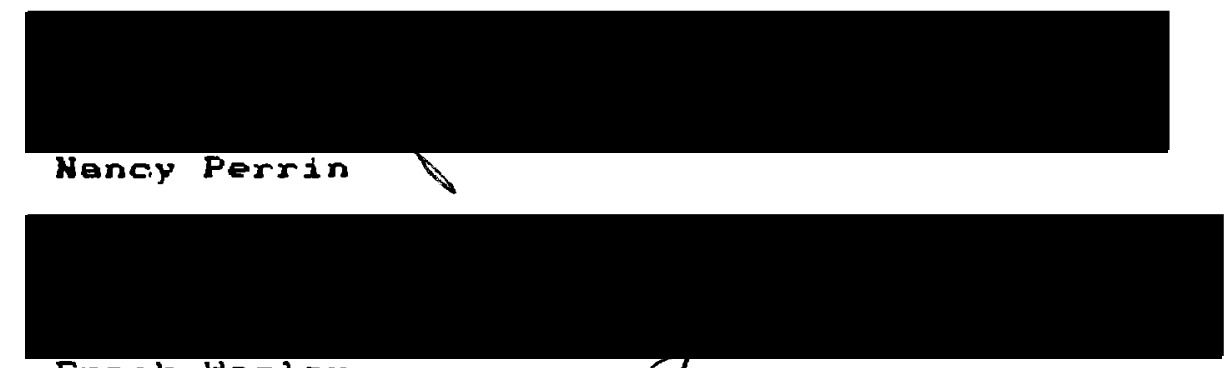
Frank Weeley

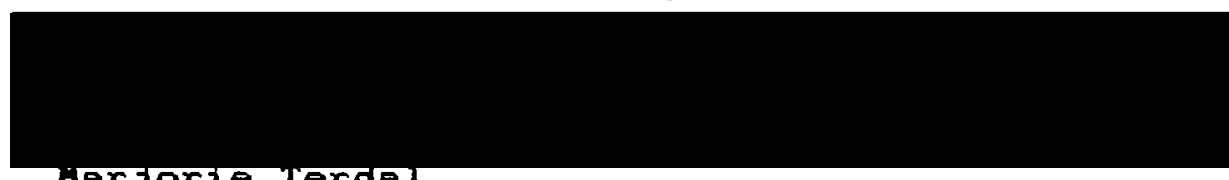

Hersorie Terdal

A reviev of the litereture suggests a caincidence of personality characteristics among the cognitive styles defined by Field Dependence-Independence and the Myere-Brigge type preferences. This thesis propased these independent measures of cagnitive style tap coman cognitive processes and hypathesized the Myers-Briggs dimensions af Extraversion- 
Intravereion (EI), Sensing-Intuition (SN), and JudgmentPerception (IP) would carrelate positively and ThinkingFeeling (TF) wauld carrelete negetively uith the dimension Field Dependence-Independence (FD-FI) es meesured by the Group Embedded Figures Teet (GEFT). The reletionships of gender. age, and intelligence to the prediction of fielddependence-independence vere elso tested. The Myers-Briggs Type Indicatar (MBTI) and the Group Embedded Figures Test (GEFT) vere administered to 202 undergreduete etudents. significent reletionshipe were found for the GEFT and the MBTI variables, $S N(r=.3121, E=.0022)$ and $I P(r=.2236$, $p=.0303)$, and for the GEFT and Intelligence $(x=.4970$. $P=.0003$, but for males only. SN and IP correlated elgnificently $(r=.3820, p=.0001$ ) for the mele group es did $T F$ and ege $(r=-.2186, p=.0343)$. Far the femeles. eignificant intercarrelations vere found for SN and IP $(r=.4222, E=.0001), \mathrm{SN}$ and $T F(r=.1867, E=.0530)$ and JP and $T F(r=.3868, P=.0001)$. Patterns revealed through a comperison of the present study with the Carmen-plett (1988) end Luek-Wright (1983) studies suggest time ellocated to cognitive proceselng wey eccount for the veriance shared by the GEFT and the SN dimension of the MBTI. 
A CORRELATIONAL STUNY OF COGNITIVE STYLE MEASURED BY

THE MYERS-BRIGGS TYPE INDICATOR AHD

THE WITKIN GROUP EMBEDNEN FIGURES TEST

by

LEITH WOOD MUESSLE

A theeis eubitted in pertiel fulfiliment af the
requiremente for the degree of
MASTER OF SCIENCE
in
PSYCHOLOGY

Partiand State Univereity

Iuly, 1989 
TO THE OFFICE OF GRADUATE STUDIES:

The memers of the commite epprove the thesis of

Leith Waad Muesele presented July 18, 1989.

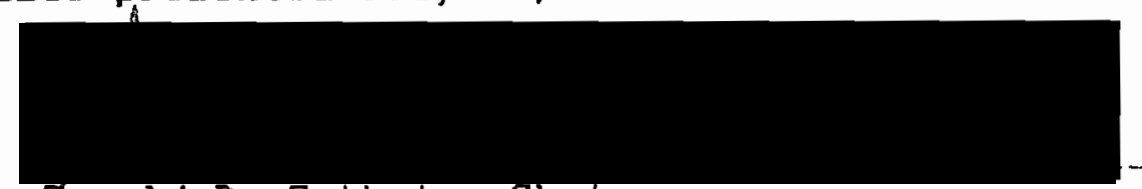

Cerald D. Guthrie, Chair

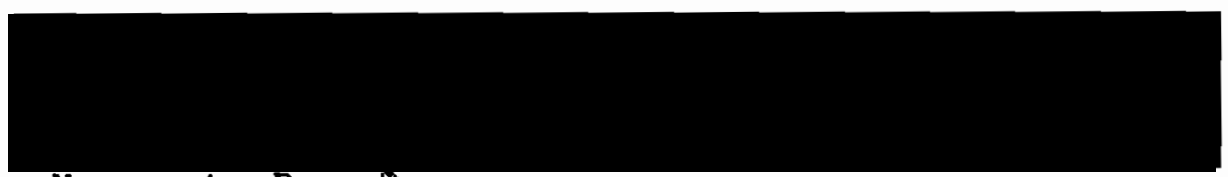

Nency A. Perrin

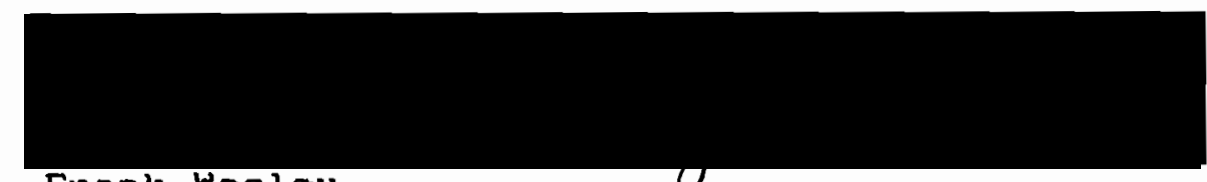

Frank Wesley

U

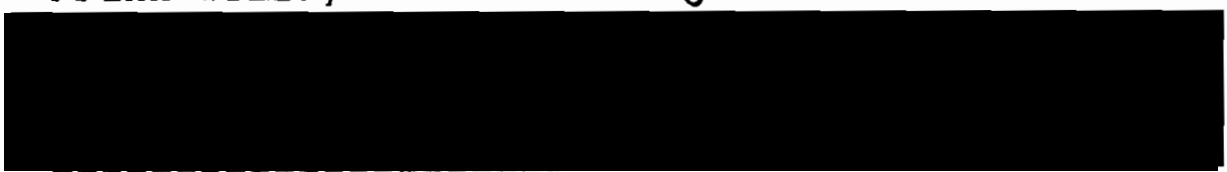

Merjarie Terdel

APPROVED:

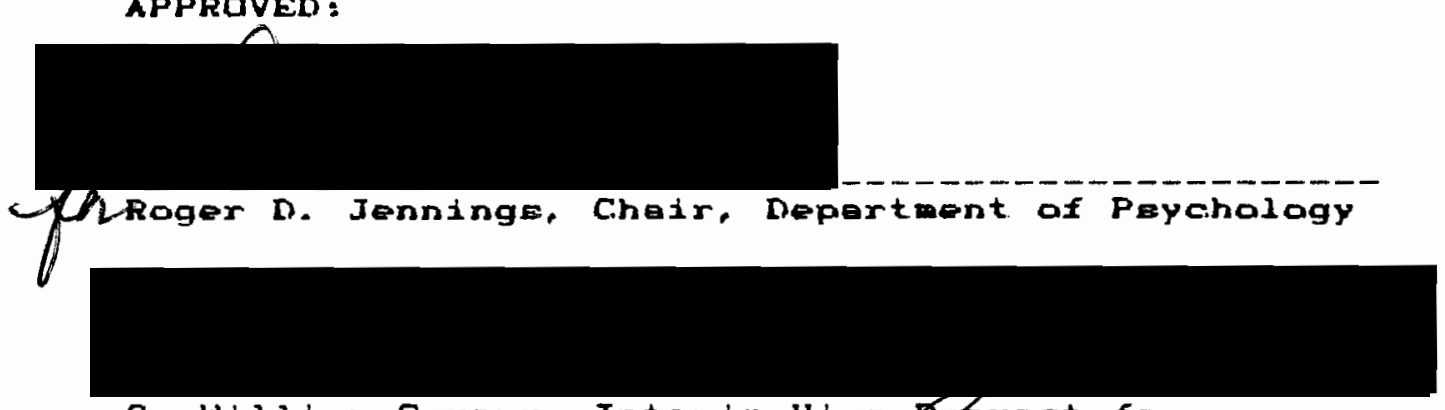

C. William Severy, Interim Vice Epovost for

Gredurte Studies and Research 


\section{AC.KNOWLEDGMENTS}

My gratitude and best vishes fallov oll the members of the Peychalagy Department, faculty and staff alike, wha, vithout exception, eo unstintingly shared their thoughte and expertise with me thraughout my years af study at Partland State University. Special thenks go to my themie committee membere, Jerry Guthrie, Nancy Perrin, Frank Wesiey and Marfarie Terdahl who each cantributed greatiy. uniquely, and emathly to the thesie pracese. 
TABLE OF CONTENTS

PAGE

ACKNOWLEDGMENTS . . . . . . . . . . . . . . . . . . . i11

LIST OF TABLES . . . . . . . . . . . . . . . . . . . . . vi

LIST OF FIGURES . . . . . . . . . . . . . . . . . . . . v1i

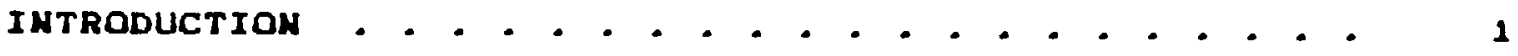

Review af the Literature . . . . . . . . . . 3

Suggerted Reletionmipe Between Field DependenceIndependence and the KBTI DImensians . . . . 7

Field Dependence and Extraveraton

Field Independence and Introvereian

Conflict, Hoatility, and Conformity

Intelligence

Ambiguity

Sonsetion Seeking

Creatiuity

Drug Dependence

Gender Differencer

Hypothomer . . . . . . . . . . . . . . . . 16

METHOR . . . . . . . . . . . . . . . . . . . . . 18

Subjecte . . . . . . . . . . . . . . . . . 18

Inetrubente. . . . . . . . . . . . . . . . 18

Procedure . . . . . . . . . . . . . . . . 22

RESULTS . . . . . . . . . . . . . . . . . . . . . . . 23

DISCUSSION . . . . . . . . . . . . . . . . . . . 31

Summery . . . . . . . . . . . . . . . . . . . 31

Anelyata . . . . . . . . . . . . . . . . . 33 
PAGE

Conclueton 38

The GEFT-SN Reletionehip an Function af Timo

Alloceted to Cognitive Praceres

The Reletionehip of Intelisgence to the GEFT,

Talerence for Ambiguity. and Cognitive

Complexity

The GEFT-SN Reletianehip on a Function of

Nontraditionel. Gender-roleted Preference

The GEFT-SH Roletionehip a a Function of Gender

The Velidity of the Field Dependence-Independence and Myerm-Brigge Meneure:

Recompendetions . . . . . . . . . . . . . . . . .

REFEREMCES

APPENDICES

56.

a SAMPLE hEANS and standard deVtations for geft,

MBTI, INTELLIGENCE AND AGE FOR THE

CURRENT STURY BY GENDER - . • • • • . 56

B POLAR DISTRIBUTION OF CURRENT STUDY'S SCORES

FOR THE MBTI SCALES AND THE GEFT

BY GENDER - . . . . . . . . . . . . . 57

C PERCENTAGE DISTRI BUTIONS OF SUBJECTS AMONG

MBTI TYPE CLASSIFICATIONS,

CURRENT STUDY AND MBTI DATA BANK.... 58 


\section{LIST OF TABLES}

TABLE

PAGE

I Peerian Correletions Among Verieblee

for All Subjectr . . . . . . . . . 24

II Pearson Correletions Among Veriebles

for Meles . . . . . . . . . . . 30

III Peermon Correletiona Among Verieble:

for Femeles . . . . . . . . . . . 30

IV Summery and Comparteon of Resulte from

the Current Study, the Corman-Platt

Study, and the Luak-wright Study . . . 34

V Percentegen of TF-SN Scoren for

the Current Study, the Cormen-Plett

Study, and the Luak-Wright Study . . . 35 


\section{LIST OF FIGURES}

FIGURE

PAGE

1. Suggeneted correlationer Myera-Brigge type preferences and fleld dependence-independence. 


\section{INTRODUC.TI ON}

Cognitive remench originated uithin diverse epprasches to the study of humen behevior reaulting in a de facto eecterianiem among thought and theory regarding cagnition and cognitive styles. Although current inventigetions continue to reflect or relete primerily to their traditionel fields of origin, the broed and intriguing essorteent of dete produced by these verious maurces is incrensingly subjected to comperetive etudies by progentiets vililing to ehift perspective frov the theoreticel differences onong the opproeches to a consideretion of their provinent commonelity --thet eech probes the seme ephere of Intellectuel

functioning. In tive, this convergence of remerch should integrete end clerify meny of the leeues perteining to cognitive mcioncep it mey einimize duplicetion of effort end atimulate on even mare fruitful and colleboretive Investigetion into cognitive procesem.

Among the constructe emerging from remearch in cognitive stylez ere en errey of bipoler continue reprementing dimensione of individuel cognttive preferences or ebilities. Bipoler or dichotomoue propertien of cognition heve been indiceted by investigations into the duel neture 
of memory (Alper, 1987), the differentiletion of the cerebral hewlepheres (Sperry, 1982), fleld dependence-independence (Witkin ( Goadenough, 1977), end the dimenetone of Jungien typology (Hyere ( McCeulley, 1985). The eimileritieg in conetructe derived frow theme different arees of regearch into cognition suggeet they top a common fectar uithin the neture of our cognitive functioning end invite further reviev and comperiman.

Aleo of interest ere the eielieritien in beheviore eseacieted vith certein dimensions of the verious epproeches. A correletion betueen right hemiepherici ectivity end field dependence wes inferred frow dete indiceting left-gezers shere elmiler porsonelity ettributes uith field dependents end ves muberequently demonetreted in leboretory etudies (Devitt \& Averill, 1976, Gur, Gur \& Herrie, 1975, Kocel, Gelin, Ornetein \& Merrin, 1972). Other compeliing einileritien af descriptive dete ere found betueen tuo eeperate bodife of vark in cognttive etyles, field dependence-independence end Iungion typology. These typez af eimilerities reaccur too coneletently throughout the 11terature genereted by these tuo fielde of reeench to epper eccidenteliy calncident end heve prompted thie thesie thet field dependence-independence and the dimeneione of Jungien typolagy ere releted. 


\section{REVIEW OF THE LITERATURE}

The field-dependent-1ndependent and the Iungien formulatione of cagnitive etyles differ primarily in arigin and focus. The vork leading to the concept of field dependence-independence begen in the leboratory of the Gentelt1et, Max Wertheleer, end wes furthered by studien conducted by Hermen witkin throughout the period beginning in the eerly 1940'a until his death in 1979 (Goodenough, 1986 ). The properties emacieted vith field dependence-independence emerged from abeervetione of subjecte' renge of ablitty in recognizing the upright or perpendicular in emblguous eltuetione which did not provide the usual vieugl cues of the upright found in everydey environmente. The most common testing epperetue in this early period was the Rod and Frewe Teet (RFT). Subjecte who coneletently eligned the rod with the nonupright freme in order to epproximete a true perpendiculer vere coneldered field dependent; those who coneietently menipuleted the rad into on upright position Independently of the cuen provided by the frewe vere coneidered field independent. Exteneione of these etudien Indiceted disembedding temke, particularly those requiring the identification of a siple design vithin a mare complex design, shered variance with the RFT, as a result, the Embedded Figuree Teet (EFT) and the Group Embedded Figuren Test (GEFT) beceme popular inetrumente for eseeneing field 
dependence-independence. A theory of peychologicel differentiation eloviy eccumulated shout the dete derived frow theef testa. Yet, as lete es 1963, the vark in field dependency west reforred to in terwe of "a weenure in eearch of theary" (21gler. 1963$)$.

The secand epproach, besed on Cerl Jung's theory of peycholagicel types (1921, 1971), vee developed by e wotherdeughter tere, Katherine Brigge and Ieebel Brigge-Myers. Like field-dependence-independence resenrch, the Jungien or Myers-Brigge eppranch relies upon a perticuler eensure to provide indiontione of the behevioral dietinctions requisite to ite theary of cognitive etylen. Thie instrument, the Myere-Brigge Type Indicetor (MBTI), eseessen four dimeneions of cognitive preferences (a) ettitude in terme of extreveraion or introvereion, (b) perception in terme of eeneing or intuition, (c) judgeent in terme of feeling or thinking. End (d) sode of deeling vith the outeide varld in terme of perception or judgment. Unlike the investigetion of fleld dependence-independence uhich elovly genereted theory of peychologicel differentiation, the Myere-Brigge dimensione vere prediceted by Iungian theary and developed es a were of utilizing that theary rether then teeting 1 t.

Several inveatigetore unafilifated uith either the Witkin or the Hyere-Brigge groups heve been iopreneed by the Implicetione thet the eeesuree for field dependency and the MBTI do Beew to ameene factore integral to humen cagnition 
and behevior. For theee independent reseercherm, hovever. the question of juet vhet is being meanured remeine open. One such peir, prompted by a citique of the MBTI uhich muggemted the Extravermion-Introversion (E-I) dimeneion related wore to ease of interpermonel contact then affinity to Ideation (Mendeleahn, 1965), hypotherized and demonetrated thet extreverte would be wore likely to scare as internala on the Rotter Locue of Control Scale and Introverte vould be more likely to soore externels. They noted thet "more attention should be given to. . . empiricel relationehips among preference instrumente than to their alleged theoreticel baees per ge" (Eliot \& Herdy, 1977, p. 430 ). Another team of investigetore aleo suggented thet, although the scales of the MBTI provide a meenure of eurfece cherecteriatice, they "do not necenearily weanure the Intended peychologicel constructe, and thus the uees of the eceles wuet be empiriceliy rather then theoreticeliy derived" (Carmkadon 2 Knudmon, 1978, P. 483). A eritic of the theory of peychologicel differentietion ecknowledgee thet, neverthelese, "there has been the undeniable muggestion in Witkin'a vork that $h i=$ inetrumente are sawehov tepping the very vellepringe of behevior... " (21gler, 1963, p. 134 ). There 1: also the ergument that Pavlou, Eyeenck, and Witkin heve each described the consequences of neurel patterning. but have done to in different vaye (Robinean, 1983). And, ve are verned thet a feilure to meintein distinctions betveen 
Inetrumente and their theories cen leed to erroneous conclusions-particularly far instruments such an the EFT and the MBTI which ere wost aften invalved in carrelationel etudies (wechtel, 1972 ).

It 1 s notevarthy that these two meparate bad1es of endervar uith dietinctly different origine and distinctly different instrumente of meseurement have cape to ehere thearoticel milarities. Bath or "type" thearies which ageume humane are barn vith or begin to ecquire at en early age - propeneity to fevor certain cagnitive functione over athers. Myere and Maceuliey, In their refarmuletion af the Jungien orientetion, explain that "children are... motivated to exercige their dominent function, becoming mare akiliful, adept, and differentiated in its uBe" (1985, p. 14). They further abserve that as individuale vith differing preferences develap elang divergent ilnes, each becomen "reletively differentioted in an area where the other remeinm undifferentiated."

The theary of peychologicel differentiotion es initieliy reparted by Witkin, Dyk, Feterman, Goadenough, and Karp (1962) vee lean muccinct. 2igler noted thet it ie preciaely here, in their theareticel efforta that the wikin graup promisen so wuch and delivers so little" (1963). Hovever, In 1976 uttkin expleined that "People with fielddependent or field-independent cognitive styles are different In their interpereanel behaviar in vays predicted by the 
theary of pyecholagicel differentietion" "Witkin \&

Goodenough, 1976, p. 661). His lest vord on differentietion, uritten ehortly before he died, explaine thats

.. differentiation $1=$ mejor formal property of

an orgenismic aysten. A lese differentiated

eyetem 1 e in a reletively homageneous ateter a

mare differentieted ayste is in a reletively

heterageneour stete. A system thet 1 is more

differentieted shove greeter eelf-noneelf

ergregetion, eignifying definite bounderies

between. . .eelf. . . end the outer vorld. In

- lese differentieted syetem. . . there $1 \mathrm{~s}$

greeter connectednese between self and others.

(Witkin, et al., 1979, p. 1127)

Both theorles elso emphesize the neutrel velue of the

cognitive etylee demeribed by each. The witkin group

clerifiex that "uith regard to velue judgments, oagnitive

etyles ere bipoler. . eech pole hes edeptive value under

Epecified circumetencer, and so way be judged positively in

reletion to thoef circumetances" (Witkin, Maore, Goadenough \&

Cax, 1977, p. 16). A reulewer of the Myerm-Briggin typolagy

echoes the Witkin group. "Ho one preference or type $1 \mathrm{E}$

thought of ef being quelitatively superior to enother...

eech preference and type hes 1 ts strengthe and 1 mplied

weaknesses, though the positive perspective is encouraged

. . (W11118, 1984, pp. 483-484).

SUGGESTED RELATIOHSHIPS BETWEEN FIELD DEPENDENCE-INDEPENDENCE

AND THE MYERS-BRIGGS TYPE DIMENSIONS

This study doen not directly addrese the theoreticel

asaumptione surrounding the Witkin and the Myera-Brigge 
Inetrumente, but egke if the Ingtrumente derived from the two epprogche weasure common elemente of the eame cagnitive procenefe. The literature zuggeate they do. Am preaented in Figure 1, patterne of definitioneliy dichotomoue preferences, abilitiea, or predispoeitione arising from regerch ueing the Witkin or the Myera-Brigge meamuree appear to peraliel each other in a predictable faehion. Field dependence eppeare to Ehare variance vith the extreuereion (E), aeneing (S), feeling (F), and Judgment (I) poles of the MBTI, and field Independence oppeare to ehare variance vith thetr palar oppoeiter, introvereion (I), intuition (N), thinking (T). end perception (P).

\section{Fíeld Dependence end Extraguereison}

Deecriptions of the personel ettributes efeociated uith the Hyere-Brigge and Witkin typee are one of the firet Indicetione that theoe etyles way be releted. Fielddependent permone hove been descitibd as saciable, gregarious, effiliation oriented, eocialiy outgoing, perticipetive, friendly, helpful, concerned for others, and having a vide acquaintanceship lLovelese, 1972; Pemberton. 1952; Souea-Paze \& Rohrberg, 1976; Sousa-Poze, Rohrberg \& Schulman, 1973). Similar terme used to demcribe extraverted pereong include "Intereste vide, enthueiestic, forgiving, aaciable, energetic, outgoing, frank, telketive, eponteneoue. 


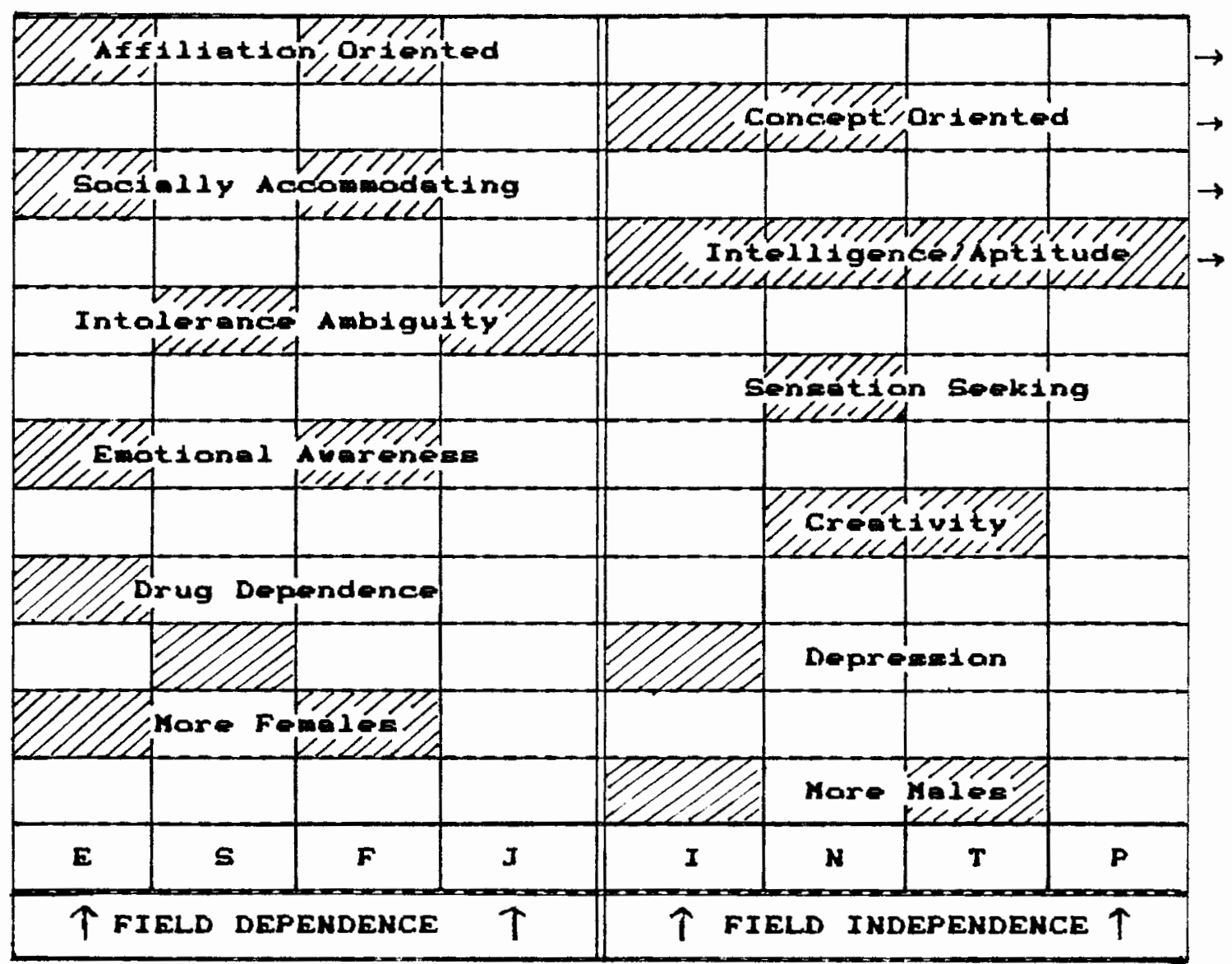

Flgure 1. Suggemed correletions Myere-Brigge Type Preferencer and Fleld Dependence-Independence.

aggremelve, quick, [end] asemrtive" tBrooke \& Jahnsan, 1979. P. 747 ).

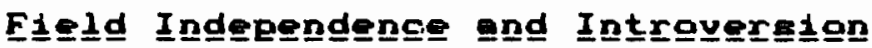

At the other ende af these two dimensione, field independenta hove been deecribed as preferring ealitery activitien, individuelistic, coal and digtent in reletions with others, moof, uninteremted in humenitarien activities, 


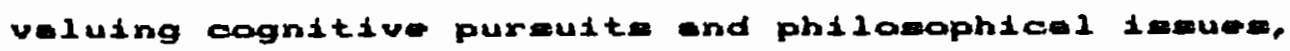
concerned with Ideea and principlen rother then with peaple, teak-orlented, Ind heving wark-orlented veluem such ea efficiency, contral, campetence, and excelling l Lovelems, 1972, Pemberton, 1952; Souse-Poze \& Rohrberg, 1976; SausaPoze, Rohrberg 2 Schulwen, 1973). Introverted permons ere reportedly "quiet, remerved, ehy, defeneive, mild, carelezs.

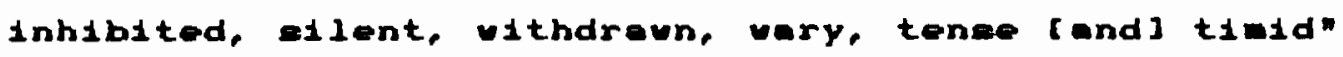
(Brooks \& Johneon, 1979, p. 747). A Myere-Briggs eseemement of the pereonelitie: of 2165 chemepleyere encerteine the chemepleyere were "eignificently nore introverted, Intultive and thinking end convereely lese extreverted, seneing and feeling than general population naraen (kelly, 1985. p. 2821.

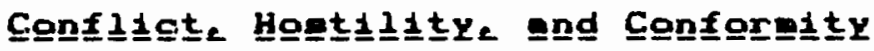

Remeerch explaring ethade far meneging canflict end homtility hes almo described parellel differences af atyle between the types. Although field-independent people premented themelver as able end uiliing to direct haetility ageinet others, field dependente vere found to evoid direct expreneions of hostility (Dengerink, d'Leery \& Kener, 1975 ). Field dependente eleo demanetreted greater consideretion for the emotionel content of =1tuetione then field independente (Westbrook, 1974). A zudy uning the MBTI reparted extreverted individuela' combined ecores on conflict-made 
teret Indiceted a tendency toverd Integretion, emertiveneme end cooperotion, and thet a preference for feoling (F) on the thinking-ferling (TF) scelo elgnificently corroleted to eccomadetion in a conflict eituetion $(K 111$ men Thomeg. 1975). In enother study, oxtreverted-feeling (E/F) end extraverted-eeneing (E/S) typer together exhibited etgnificently wore conforming beheviore then did introvertedthinking $(I / T)$ and introverted-intuitivo (I/N) type: (Natheye, M1110r \& Cergkedon, 1981 .

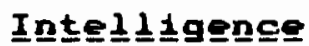

Both the INTP poles af the MBTI and the witkin dimeneion of field independence epper to be more correlative vith Intelilgence or eptitude neagureg then ore their counterperte. Although Witkin'e Embedded Figureg Tegt (EFT) hel been shoun to carrelete uith perfarmence on etenderd Intelijgence teste, a fector enelytic atudy indiceter 1 t logde on en uncorrelated foctor ag vell. UEere are coutioned thet the scelo ary yleld oleleoding end ambigour informetion (Robingon, 1983). Wechtel commente thet inderdp the terte af field independence most cononly used correlete juet ar highly vith the Block Designe, abject Assembly, end Pleture Completion eubterse of the Wecheler Adult Intelligence Scele of they do uith eech other" (1972, p. 191). The INTP paleg are the only ones which consigtontly and eignificantly correlete uith verious inteli1gence end aptitude terte? 
hovevar. INTJ if moet frequently correlated uith acedemic achievement megeurea (Myere \& McCeuliey, 1985). It ia noted thet J'e tend to overechieve end P'e to underechieve.

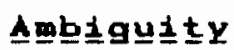

To ectivete many of the field-dependent responser. ambiguity muet be introduced into e eituetion. FieldIndependent individuele appeer more comfortable than fielddependent individuele in circumetances in which an intorpretetion of etimuli ie not immediately epparent. Field dependente are believed to perceive embiguoue eituatione es sources of peychological diecomfort or threat beceuee they are more $11 k e l y$ to look to or eep out othere for informetion to diepel the ambiguity (Hit.kin \& Goadenough, 1977 ). In educetional eettinge, field-dependent etudents heve been found to heve greoter difficulty in learning reletively unetructured weteriel then field-independent etudente. When the meteriel to be learned 1 e premented in vell orgenized form, both types oppear to learn it uith equal eage luitkin, Moore, Goodenough, \& Cox, 1977). When MATI-type preferences vere terted againet sceleg for intolerance of embiguity. eneing (S) and Judging (J) correlated eignificantiy vith Intolerance for ambiguity (Myere i McCeuliey. 1985). Being disconcerted by embiguity may leod to the uee of black-andwhite eolutions, cetegorizetion, premature clomure, end, af coures, avoidance of ambiguous eituetione chapelle i 
Roberte, 19e6), thi= in itmelf could preclude muportor performence in the intellectual real domineted by field Indeperdence end the INTP preference.

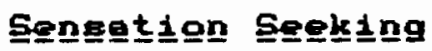

Another varieble which may correlete with field Independence end the intuition (I) preference af the MBTI is eeneetion meeking. In studies using the Rad and Freme Test (RFT) (Zuckermen \& Link, 1968) and the Embedded Figuren Teet (EFT) (Zuckermen, Kalin, Price \& Zaob, 1964), meneotion seeking wes found to carrelete vith field independence far malee but not far femeles. Reseerch employing the MBTI reported eeneing (S) preferences carrelated negetively and intuition (N) preferencer correleted poeitively vith the Arougel Seeking Tendency Inetrument and the generel Sensetion Serking Scele (Goldsmith, 1950) for both weles and femeles.

\section{Cxeetiugity}

The finding that field-independent persone an a group ere pare creative then field-dependent persone hes been discuesed in the context af " mobility-fixity" dimeneion which suggeste o copecity for flexibility in etyle mey exist far eome field independents, but not for others (Witkin, et 1.. 1971, p. 11). The date from research using the MBTI which indiceter creativity 1 seleted to intravereion (I) and intuition (N) could mesiet in exploring the mability-fixity notion. 


\section{Drug Dependenge}

When the RFT performance of 562 subjecte hospitelized for treatment of alcoholisw wes compered to thet of narmel and peychietric groupe, the elcoholic memple was clearly the moet field dependent IJecabson, Ven Dybe, Sternbech \& Bretheuer, 1976). MBTI eneememente of the cherecterietice of drug ebuefer have reported a elgnificentiy lerger percontage of extreverte then introverte within drug-eddicted omples (B1sbee, Sullely \& Ommond, 1982, Devinne \& Johnson, 1976). It vee further noted thet, reletive to normal populatians, ISFJ, ISFP, and ISTJ typen vere overrepresented in groupe of petiente vith diegnoses of depreselon, echizophrenie, eubetence abuse, end bipoler-mentc disorder lBtebeo, et el.. 1982).

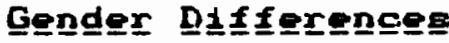

A Eeneitive lesue 1 s the coneletengy with which fieldIndependent meles autnumber field-independent femeles (Witkin, et al., 1971). This unevennese of representetion 1 e reflected in the MATI dimeneione es vell. The percentege of femelee ahoving a preference for introvereion (I) 1 : coneletentiy lover then thet for meles. The greater diecrepancy in type between the exexe, hovever, Il the preference for feeling (F) over thinking (T) exhibited by femeles. Of e semple of 5,632 mele and 9,616 femele 
tredittonal-ego coliege etudente, 562 of the welIndiceted a thinking preference contrated to $28 x$ af the femeles (Myers L HCCeulley, 1985, pp. 46-48).

A eerch af the ittereture hes yielded only two publighed etudieg which directly compere the witkin fielddependence-independence dimeneton vith the MBTI dimeneions. The firet of thege atudien (Luek a Wright, 1983 ) reported no eignificant correletiane betvern the tvo terte end almo noted thet the literoture canteined no record of priar vork compering the GEFT to the MBTI. The accond etudy lCormen s Plett, 1988) adeinistered tho tuo meneurer to undergreduete bueineme etudente end reported a eignificent correletion between GEFT ecorez and the eneing-intuition (SN) gcele af the MBTI for fowelea only.

Compelied by the euggeeted relationehipe, the provocetive deto reparted by Cormen and Plott, and the dearth af comparetive research ueing the Witkin and Myerg-Briggs Inetrumentop thie etudy 10 undertaken to incromer our inventory af cognitive Etyle. The Myere-Brigge Type Inventory (MBTI) vili be used to beegure the Myerg-Brigge type preferences and the Group Embedded Figureg TeEt (GEFT) v11 be ueed to meneure field dependence-independence. 


\section{HYPOTHESES}

H1, There will bo a postive correletion betveen the MBTI extrevereion-introvereion dimeneion (EI) and field dependence-1ndependence (FD/FI) ae measured by the GEFT.

H2, There vill be paeitive carreletion between the MBTI eeneing-intuition dimension (SN) and field dependence-independence (FD/FI) an mereured by the GEFT.

H3: There vili bo e negetive carreletion betueen the MRTI thinking-feeling diefneion (TF) end field dependence-1ndependence (FI/FI) as measured by the GEFT.

H4. There ulli be poeitive carreletion betueen the METI fudgment-perception dimension (IP) and field dependence-1ndependence (FD/FI) es meesured by the GEFT.

H5, Field dependence-1ndependence cen be predicted by combinations of MRTI veriables.

HG1 Reletionghipe between field dependenceIndependence and the MBTI veriablen ere not molely - function of ige.

H72 Relationshipe between field dependenceindependence end the MBTI veriables ere nat ealely a function af intelilgence. 
HB, There will bo gender difference in the prediction of field dependence-independence frow the MBTI veriables.

H9, The equetion far males will predict mare variance In field dependence-independence then the equetion for femplen.

H10. The best predictar veriables for field dependenceindependence will be different for welem and femelem. 
METHOD

SURJECTS

The MBTI and GEFT vere edminietered to 202

undergreduete etudenta, 108 fereles and 94 meles, enrolled in undergreduete peychology courees et Portland State

Univereity. Half the eubjecte, 52 feneles end 49 ones, also took the Wonderlic. Perzonnel Teet, Fore II. Subjecte' agem renged from 18 to 58 vith on everage age of 24 . They received extre credit in their peychology courses for participeting in the study. No informetion regerding the theneif or the tent infetrumente ven provided to the eubjecte hefore teating.

\section{INSTRUMENTS}

Two teet inetrumente, the Group Embedded Figuren Test (GEFT) and the Myerm-Rriggs Type Indicetor (MBTI) Form F vere ueed to esmere field-dependence-independence and the MyereBrigge cognitive-etyle preferences.

The GEFT is a group edeinietered, pencil-end-peper, speed test designed to eppraxionte the individualiy edeinistered EFT. It consiste of three sections--e verm-up eection of eeven triale end two teet mections of nine triele 
each. For egch trisi, the eubject ie agked to find and trace. vithin the context af a more complex figuro, the form of a previauely pregented eimple figure. It teker appraximetely 20 ainuter to adminigter. Tuo minuter are elloved far the verm-up eection, end five minuter ere alloved for mech af the tegt mections. Eech aubject receives end completer the teet vithin an individuel test baoklet. The GEFT ecore caneietg of the number af itgureg correctly identified.

correlatione betueen the ecorem from the firet eqcition af the GEFT uith the ecores from the eecond section corrected by the Speermen-Brown prophecy farmula has produced a reliability estimate of . 82 for both meles (N $=80)$ and fomeles (u $=97$ ) (witkin, et al., 1971). These religbility ertibetes ere reparted to compere favarebly with those of the EFT.

The validity of the GEFT is beeed an ite correlatione vith the EFT (-.82, -.63), vith the Porteble Rad and Frame Teet (PRFT) (-.39, -.34 ), and with e megeure af degree af body articulation $(.71, .55)$, for meleg end femeles reepectively. Theee correlatione vere beed on emell

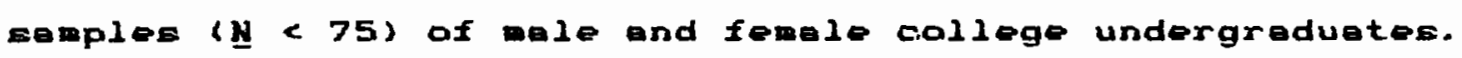
The correletions uith the EFT and the PRFT are negetive

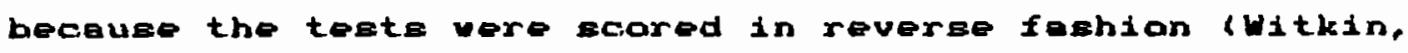
et $01 ., 19713$

A question af the velidity of the EFT es a megsure af 
field dependence for femelem ves releed in 1967 by Thorton and Berrett af Goadyeer Aeraspece Corporetion. According to their enalyain, the EFT ecores for vowen had a correletion of .21 uith the RFT compered to an EFT correlation of .64 uith the RFT for wen. They conclude it 1 is en lnvolid meesurement of field dependency far femeles.

The ebeence of replies to or citetione of their article in the 11tereture indiceter the Thorton end Barrett question has not become - burning concern far the prychometric community. A recent reviev of the EFT (LeVoie, 1984) etetes thet "extensive information 1 a aveileble? to gummerize it briefiy. the EFT hes greeter velidity for melen then femeles" (p. 264). The EFT if recommended as a solid test "uith many immediete end potentiel epplications."

The Myere-Brigge Type Indicetor (MATI) Form F, en untimed, eelf-report inventory, conelete of a booket conteining 166 forced-cholce itewe to uhich wubjecte reply on - eperete enever sheet. Most of the questione heve only two poesible enevere. Examples "In it higher praiee to sey momeone has (A) Vizion, or (B) common senge?" A partion of the MBTI conteine vord palre from which the subject is enked to choose the vord utth the moet opperl beeed on meening. The MBTI preference ecores are e reformuletion of the difference ecores for exch dimeneion. They are converted to continuous scares for correletive studies by edding the 
INTP score to 100 and mbtrecting the ESFI scorer from 100.

The MBTI consietently recelves paseing merke as a

reliable and generally velid inetrument (Cerlean, 1985 ).

Carlyn noter thet "estimated reliebilities of type cetegaries appear to be eetiefectory in most cesese although there $1=a$ rether vide range betueen caneorvative and 11 berel estimater of internel coneletency" (1977, p. 465). Intercorreletione of type-ontegory scores and intercorreletions of continuous ecares both Indicate relative independence betueen the type dimeneione vith the poesible exception of the judgmentperception (IP) scale which appeare to consiatently correlote poeitively vith the eoneing-intuition (SN) ecele. This 1 e of perticular theoretical interent beceuge Jung postulated only three type dimenelone, EI, SN, and TF. The fourth dimeneion, IP, ver added by Imabel Myere (Myere 2 McCeulley, 1985 ). Carlyn's reviev of the MBTI's content velidity. predictive velidity, and conetruct volidity pronounces 1 t "a remeonebly velid instrument" (1977, p. 471$)$. It hes recelved further suppart os instrument which hes "esteblished an impreseive record of relieblitty and velidity when mployed in eppropriate remerch contexta" (Cerlean, 1980, p. B02). The Wonderlic Permonnel Teet, Form II, 1 a a timed (12minutel, generel meenure of mental ablitty. It $1=$ not nowineliy designeted as such in order to allay the testteking enxiety which wight be greater for an instrument 


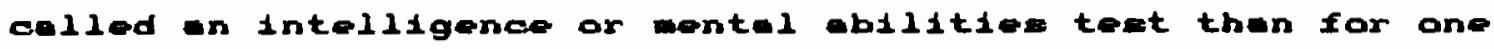
colled a "pereonnel" temt (Wonderlic, 1983 ).

\section{PROCEDURE}

The edminietretion of the GEFT requires more mubject

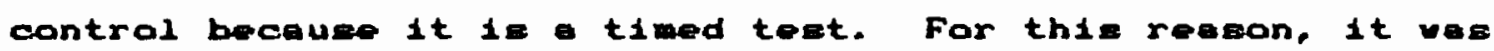
the firet ingtrument premented to the iubjecte. After the GEFT ves collected, the cubjecte vere given the MBTI to complete at their oun pece. The epecific zotg af verbal Instructions accampenying each instrument vero read to the eubjecte by tho experimenter.

The Honderlic vas adminietered en a follov-up tont to the eubsepple af 101 subjects on a epprete dey. 


\section{RESULTS}

The appendices contain three tables eummerlaing the eample in terme of MBTI and GEFT scores by gender. Appendix A presente means and stenderd deviatiane far the MBTI sceles, the GEFT, Intelilgence as measured by the Wonderlic, and for the subjects' ages. Appendix B providen the poler distributions of the current study's mares far the four MBTI sceles and the GEFT. Appendix C. compares the percentages of this study' male end femele subjects enong the sixteen MBTI type cetegaries to the percenteges of types represented by the pele and femole semples of traditionel-age college etudents frow the MBTI Deta Bank (Myers \& McCeulley, 1985 ).

This study's ten hypotheses and corresponding test resulte are presented below. The correletions emang ell veriables for ell subjecte ere summerized in Table I.

H1: There will be a positive correletion between the MRTI extrevereion-1ntravereion dimeneion (EI) and field dependence-independence (FD/FI) an measured by the GEFT.

The carreletion af EI end FD/FI wes. 0415, which 1E not Eignificent at the elphe. 05 level. Therefore hypathesis 1 ves nat. eupported. 
H2: There 1111 bo - pomitive correletion botvern the MATI Beneing-intuition dimeneion (SN) and field dependence-1ndependence (FD/FI) es weerured by the GEFT.

TABLE I

PEARSON CORRELATIONS AMONG VARIABLES FOR ALL SUBJECTS $\begin{array}{lllll}\text { GEFT } & \text { SI } & \text { TF } & \text { JP } & \text { INTEL }\end{array}$

EI $\quad 0.0415$

SN $\quad 0.1776 * \quad-0.0097$

TF $\quad-0.0553 \quad 0.0064 \quad 0.1029$

IP $0.1702 * 0.07250 .4027 * 0.1106$

INTEL $0.3927 * \quad 0.0809 \quad 0.1550 \quad-0.0867 \quad 0.1209$

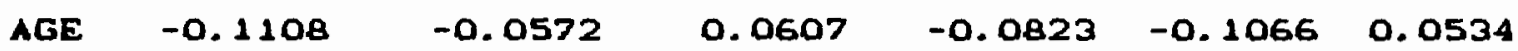
---1-.-

$\underline{N}=202$ for ell verieblen except intelilgence $n=101$

$\rightarrow 0.05$

This hypothesis ves confirmed vith an $r=.1776$

$(P=.0114)$ Indiceting subject scoring oe field independente ere more likely to repart areference for eituations in

which they perceive thinge more conceptueliy then an eitepler, sensory beaia.

H32 There will be e negetive correletian between the MBTI thinking-feeling dimeneion (TF) and field dependence-1ndependence (FD/FI) De eeenured by the GEFT. 
Thi hypotherie vom not eupported by the nonelgnificent -.0553 correletion.

H4, There will be a paltive carreletion between the MBTI Judgeent-perception dimeneton (IP) and field dependence-independence (FD/FI) ter meesured by the GEFT.

A correletion of . 1702 for $H 4$ ver eignificent

$1 \mathrm{l}=.0154)$ indiceting eubjecte mooring en field independente exprese a preference toverd keoping lesues open end remeining receptive to additionel informetion rather then coning to quilik conciueione or judgments.

H5. Field dependence-independence cen be predicted by combinetione of MBTI veriables.

A eignificent reletionahip between field dependenceindependence and a cambinetion of MBTI veriebles poetuleted by 45 if indiceted by almuteneous eultiple regremeion enelyeis ylelding the equetion:

$$
\text { GEFT *. 006EI +. 0235N - .018TF +. 020JP + 8.58. }
$$

The $R^{2}$ of .0511 wes eignificent $(F(4,197)=2.65, \mathrm{E}=.034)$ : however, only $5 x$ of the verience in FD/FI can be eccounted for by combinetion of the MBTI scales. None of the regreesion veighte were eignificent, therefore no eingle ecale contributed uniquely, but, together, they olgnificantly predicted field-dependence-independence.

A stepuise wultiple regreseion enelyeie ves omployed to deterwine the ordering of the MBTI variablea in terme of 
verience eccounted for In predicting FD/FI. It yielded the nev equations

$$
\text { GEFT }=.0235 N-.018 T F+.021 \mathrm{JP}+9.13
$$

which conteined only three of the four MBTI ecelen and eccounted for anly $5 x$ of the verience in FD/FI. The $R^{2}$ of .0500 ves eignificent $(F(3,198)=3.47 . \mathrm{E}=.017)$. The variebles meeting the entrence criterion of .5 Iignificence entered the equetion in the following order, sN entered f1ret, leading to on $R^{2}$ of .0315. Next, JP entered the madel end increased the verience eccounted for by $1 x$ reeulting in on $R^{2}$ of .0432 . TF entered lest, increasing the verience accounted far by on edditionel $1 x$, reaulting in an $R^{2}$ af .0500. EI mede no contribution above end beyand the ather $\sec 10 \pi$

Bath SN and IP have eignificent simple correletions vith GEFT, so it is not eurpriaing they entered the madel firet. Hovever, they almo carrelete eignificantly uith each ather, $r=.4027$ ( $=.0001$ ), thereby oppeering to eccount for some af the eame variance in GEFT. TF and EI heve very lov correletions vith GEFT uith TF accounting for different verience in GEFT then the ather verlables. The stepuise shove thet SN and IP pley the mast Impartant, yet moll, role In predicting field-dependence-independence en defined by the GEFT in this semple. There etepuine resulte should be interpreted vith ceution because the order af the tvo variables could change due to the correlation betveen SN and 
IP and boceugo of the relatively amall anplo elze for a etepu1mer.

HG. Reletianehipe betveen field dependenceIndependence and the MBTI verteblem ere not molely - function af nge.

The eed-pertiel correletion of the GEFT and the SN diemeion vith age taken out ueg. 1847 (p =.008) Indicating - Ignificant mount of tho verianco cowmon to both SN and the GEFT cennot bo attributed to age. A relatianghip above and beyond age ves eleo Indiceted for GEFT and the JP dimeneion by a emi-pertial correlation coeffictent of . 1593 $g=.023)$

H7. Reletionehipe betvern field dependenceIndependence and the KATI vertebles ere nat molely - function of intelitgence.

Thto hypotheris vas not confirmed. The metal-partiel carrelatione of the GEFT and tho SK and JP dimenmione ulth Intelijgence teken aut vere not eignificent, indiceting the GEFT end the SX dimension and the GEFT and the JP dimeneion shere little common varience thet 1 a not almo related to Intolligence az eomured by the wonderlic. Permonnel TeEt.

HA. There uill be a gender difference in the prediction of $\mathrm{f} i \mathrm{ol}$ dependence-independence frot the MATI variables.

The regreanion equatione for predicting FD/FI from the MBTI menlep vere determined epperetely for waleg end femelem. 
The enelyele for wales indicated eignificent roletionship between the GEFT and a combinetion of MBTI veriables. It yielded the equetion 1

$$
\text { GEFT }=.0201 E I+.04445 N-.0323 T F+.0170 J P+6.83
$$

uith an $R^{2}=.1435(F(4,89)=3.73, Q=.008)$. Fourteen percent of the vertence in FD/FI for meles cen be accounted for by a cambinetion of the MBTI foeles. The SN regremeton weight of .0444 van mignificent ( $\underline{p}=.0132$ ) Indicating the sN dimenetion contributed uniquely to the relationship.

A etepuleo multiple regremsion analyeis van used to provide the ordering of the MBTI varieblee in predicting field-dependence-1ndependence for eales. The nev equetion 1 e Identicel to the siculteneour equation for meles above. The MBTI veriables entered the equetion in the folloving orderl SH entered first, accounting for epproxisately $10 x$ of the verience for en $R^{2}$ of .0974. It wen followed by TF vhich Increesed the vartence eccounted for by $2 x$ resulting in en $R^{2}$ of .1201. EI entered next, edding $1 x$ to the vertence accounted for resulting in $R^{2}$ of .1342 . Finally, JP entered, increening the varience accounted for by $1 x$ resulting in an $R^{2}$ of .1435 .

Thie ordering of the veriebles for the maleg in which TF entere an the second varlable differe frov the overall ardering in which IP 1 s the eccond variable and TF te the third. 
In contreat to the remulta for the meles, whon only the females vere exemined, the elmulteneoue wultiple regreesion equetion containing the four METI eceles ven not eignificant. A etepuieo eserement of the reletionships ues not conducted because of the abmence of significent resulte for the Eimultaneaue enelysig.

H91 The equetion for malee vill predict mare varience In field dependence-independence then the equation for femelen.

Hypothesi: 9 hem heen resalved by the temt remulte for He wich indicete $14 x$ of the varience in FD/FI can be predicted by the equetion for weles vherees only noneignificent $2 x$ af the verience cen be accounted for with the females.

H10. The beet predictor veriables for field dependence-independence vill be different far meles and femeler.

Hypatheei= 10 hes: alsa been resalved by the temt roeulte for HB which indicete there ere no eignificent predictor variables far femeles vhereas the veriables entered in the following order for meles SN, TF, EI, IP.

Tables II and III are provided to 11 lustrete the nature af the carreletions amang the GEFT, the MBTI, age, and Intelligence for the males (Table II) and for the females $(T a b l=I I I)$. 
TABLE II

PEARSON CORRELATIONS AMONG VARTABLES FOR MALES

$\begin{array}{lllll}\text { GEFT EI SN TF TP TKTEL } & \end{array}$
EI
0.1450
SN
$0.3121 *$
0.0958
TF
$-0.1310$
0.0261
0.0627
IP
0.2236 *
0.0751
$0.3820 *-0.0484$
INTEL
0. 4970 *
0.0042
0.1569
$-0.0903$
0.1619
AGE $-0.1100$ $-0.0754$
0.0366 $-0.2186 *-0.1198-0.0453$
$N=94$ for ell verieblen except intelligence $n=49$ $*$. $<.05$

TABLE III

PEARSON CORRELATIONS AMONG VARIABLES FOR FEMALES $\begin{array}{llllll}\text { GEFT EI TH } & \text { TF }\end{array}$ EI $\quad-0.0623$

sN $0.0383 \quad-0.1140$

TF $0.0739 \quad 0.0457 \quad 0.1867 *$

IP $0.09780 .05260 .4222 * 0.3868 *$

INTEL $0.2403 \quad 0.1430 \quad 0.1463 \quad 0.0306 \quad 0.0011$

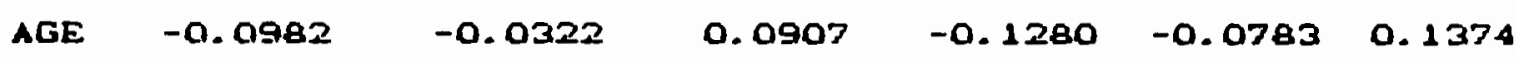

$N=108$ for all veribbles except intelligence $n=52$ $-p<.05$ 


\section{ScussIaN}

\section{SUMMARY}

Thie study ves prediceted on the thesis thet the Group Embedded Figures Test (GEFT) and the Myere-Brigge Type Inventory (MBTI) elicit dete pertinent to cognitive pracemeing and thet the two instruments access a common cognitive procenen. Five porcent of GEFT performence. overnil, une mignificently predicted by the combinetion of MBTI veriables in the directione hypothenized--INTP. Within the overell equetion, hovever, no single meele contributed uniquely. For the meles, $14 x$ af the verience in GEFT performence ven predicted by the combinetion of MBTI veriables. SN, the alngle mignificant predictar, accounted for lox of the verience, folloved by $T, I$, and $P$ uhich, tagether, eccounted for an edditionel $4 x$ of verience. Accarding to ecedentc convention, these einguler result: vould be interpreted en thaugh they vere e comprehenelve representetion of the procese under consideretion. Hovever, for this particular question other direct evidence 1 e evalable and negeter, a priari, eny lsoleted interpretetion of the present study's finding. Specificeliy, the very mimiler Cormen-Plett (1988) mtudy eleo found a Egnificent GEFT-SN correletion, but only for 
femeles, and the equally stmiler Lusk-Wright etudy (1983) found no Eignificent reletianehip between the GEFT and the MBTI for elther gender. As can be seen, when cansidered aeperately, the results of eech of these three etudies contradict the remults of the other two.

Becauge eech study tegted the reletionehip between the GEFT and the MBTI using ldenticel metertele, preforibed procedures, and edequete eemple elzen $\mathrm{CN}=202$ for the current etudy; $N=226$ for Corman-Platt; $N=103$ for LugkWright, drevn frow populations of undergraduate etudents of andlar mean egen 124.3 yeare for the current etudy: 22.38 yeare for Cormen-Platt; and 21.1 yeare for Luek-Wrights, no perticular eet of reeults cen be coneldered clearly superior to the othere. An elternative 1 e to expend the enelyals to ane in which ell three eets of remults are regerded in equeliy velid and pertiel manifeetetions of the cognitive procees under investigetion, and in which all three sete of remulte became centrel to 1 ts discuesion. Ta put 1 t pleinly, theae three eeta of perplexing dete are not mere cosmo disfunctions in the field of cognitive research but do reflect the process under exploretion. To understand the pracess, it wust be considered in its entirety.

To eccommadete this expended formet, a summery of the reeulte for the current atudy, the Carmen-Platt study, and the Lusk-Wright atudy 1 s proulded in Teble IV. A compartson of the SH-TF distributions and retion by gender for the 
current etudy, the Carmen-Plett etudy, end the MBTI Farm F Deta Bank ie premented in Table V. The Luek-Wright study did not prouide SN-TF information for 1 to subjecte.

\section{ANALYSIS}

Beceuse these etudies utilized ldentlcel procedurea end meteriale, yet produced different reaulte, their findinge appeer to depend on ample artifecte rather than a coneigtent reletionship between the MBTI and the GEFT. The GEFT-SN correletione, $r=.312$ for the current etudy's melee and $r=$ .241 far the Carmen-plett femeles, vere abteined far graupe eharing four dietinct semple cheracterietices greater renge of GEFT perfarmance, mare belenced praportiane of genderreleted $T$ and $F$ preferences, no eignificent intercorreletiane between SN and TF, and ekeved dietributione of SN preference.

The intercarrelatione between IP and SN and GEFT Indicate SN and JP ehare the seme variance vith GEFT. Thus the discuestion regerding the SN dimeneion could equeliy pertain to the IP dimension, and IP uill not be referred to mpecifically.

The relationship between the GEFT and the SN dimension af the MBTI geined eignificence uithin semples poseensing tho mare extreme GEFT scores and the mare extreme retion of Intuition (N) to sensing (S) preferences. The current etudy"s males and the Cormen-Plett femeles for whow GEFT and SN Bignificently correleted hed higher ween GEFT mcaren than 
TABLE IV

SUMMARY AND COMPARISON OF RESULTS FROK THE CURRENT STUDY, THE CORMAH-PLATT STUDY, AND THE LUSK-WRIGHT STUDY

Current study

Malea Femelea
Cormen $-P 1 \in t$

Malea Femalea
Lusk-Wright

A11 Subject:

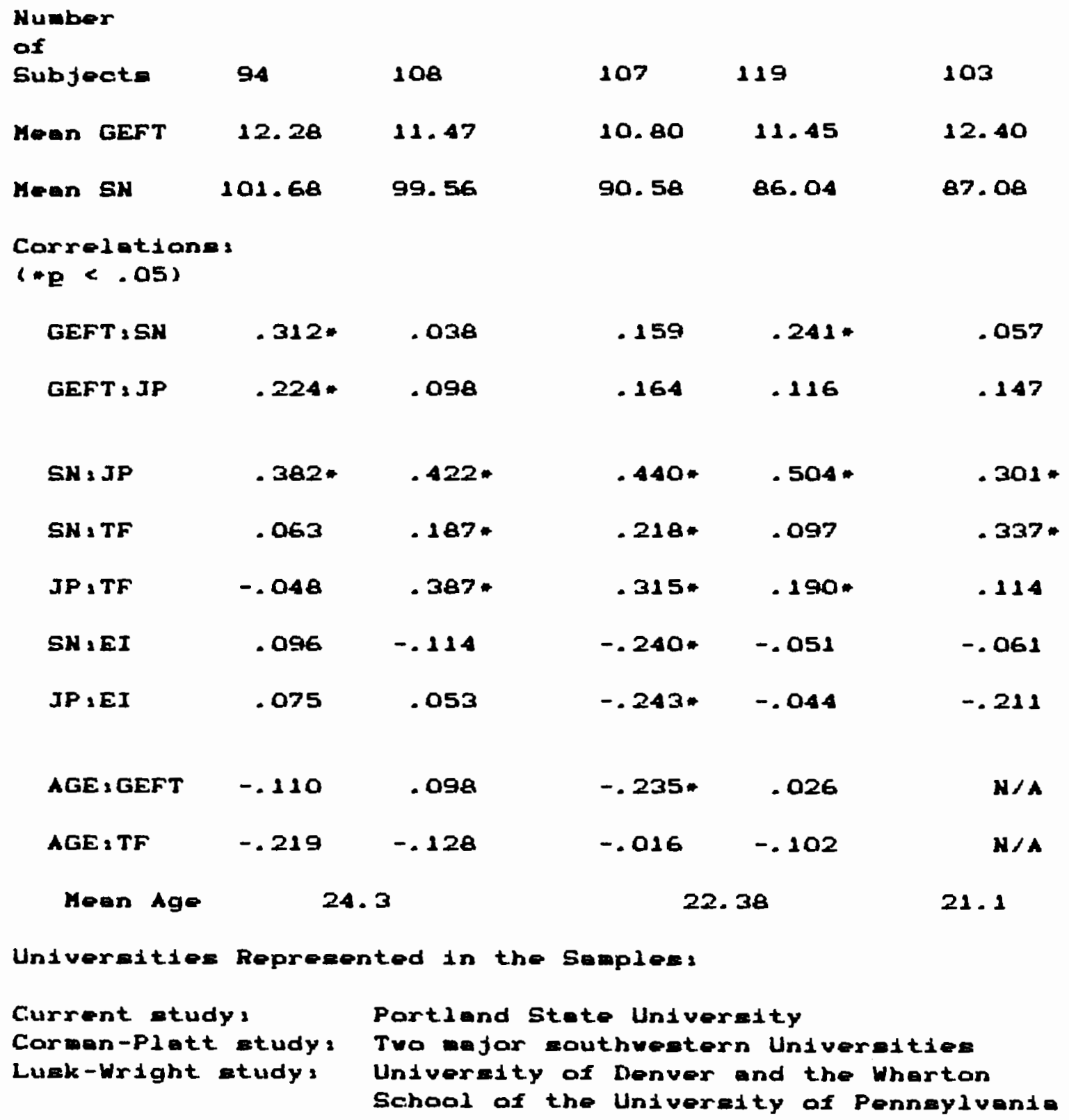


TABLE V

PERCENTAGES OF TF-SN SCORES FOR THE CURRENT STUDY, THE CORMAN-PLATT STUDY, AND THE MBTI DATA BANK

Melen

Current Study

$$
\underline{n}=94
$$

$\begin{array}{ll}\text { S/F } & \text { N/F } \\ 12.76 & 22.35 \\ \text { S/T } & N / T \\ 34.05 & 30.84 \\ \text { Thinking } & =64.89 x \\ \text { Feeling } & =35.11 x \\ \text { Seneing } & =46.81 x \\ \text { Intuitive } & =53.17 x\end{array}$

$N_{2} S=1.14$

$T: F=1.85$
Corman-Platt Study

$\underline{n}=107$

$\mathbf{S} / \mathbf{F}$

9.34

$N / F$

14. 96

$5 / T$

50.46

$N / T$

25.23

Thinking = 75.69x

Feeling $=24.30 x$

Soneing $=59.80 x$

Intuitive $=40.19 x$

$N, 5=.67$

$T, F=3.11$

\section{Femalea}

Current Study

$\underline{n}=108$

$S / F$

29.43

$N / F$

29.66

$\mathrm{S} / \mathrm{T}$

23.74

$N / T$

17.60

Thinking $=41.34 x$

Feeling $=59.19 x$

Seneing $=53.17 x$

Intuitive $=47.26 x$

$5, N=.89$

$T_{3} F=.70$
Corman-Platt Study

$\underline{n}=119$

S/F

36.13

$N / F$

17.64

$S / T$

36.13

$N / T$

10.08

Thinking $=46.21 x$

Feeling $=53.77 x$

Intuitive $=27.72 x$

$5, N=.38$

$T 2 F=.86$
Senzing $=72.26 \%$
MBTI Deta Benk

$$
\underline{n}=5,632
$$

$\begin{array}{rr}S / F & N / F \\ 23.36 & 19.94\end{array}$

$S / T$
35.05

$N / T$

$35.05 \quad 21.66$

Thinking $=56.71 \%$

Ferling $=43.30 \%$

Seneing $=58.41 \%$

Intuitive $=41.60 x$

$x, 5=.71$

$T, F=1.31$
MBTI Data Benk

$$
\underline{n}=9.616
$$

S/F

N/F

43. 14

28.79

$S / T$

$N / T$

18. 32

9.75

Thinking $=28.07 x$ Feeling $=71.93 x$

Seneing $\quad 61.46 x$

Intuitive $=38.54 \%$

$5 . x=.62$

$T, F=.39$ 
did their vithin-etudy counterperta for whom GEFT and SN vere not elgnificantly carrelated. The current etudy's weles and the Corman-platt females also hed the mont extreme ratios of $N$ to 5 preferences among the two etudien and the MBTI normetive eamplee. The preeent etudy'e group of melee contalned an uncheracterietic majority af subjecte scarling as intuitives for the highest $N$ s retio of 1.142 the CormenPlatt femelee Indiceted a $72 \%$ preference for eeneing for the lovent $\mathrm{A}$ to $\mathbf{S}$ ratio of .38. These configuretione euggest the etrength of the GEFT-SN correlations occur in the upper teil of the GEFT dietributione and thus depend upon levele of GEFT performance rather than GEFT performance overall.

A second pattern reveale an inverse relationahip tetueen the presence of significant GEFT-SN correlations and the presence of eignificant TF-SN carrelations. For the graups with eignificent SN-GEFT correlatione--the current etudy'a malea and the Corman-Platt femeles--SN and TF were not algnificantly correlated, for the groupe in which SN and GEFT were not significantly correlated--the current study's femelee, the Corman-plett melee, and the Luek-Wright group-SN and TF vere eignificantly carrelated.

The TF fector eppears to be waet closely assaciated uith traditionel environmentel influence, eapecieliy as pertaine to gender. Meles and femeles heve conelstently scared differently an the TF scele of the MBTI. According to the MBTI eamplee of 5,632 male and 9,616 female traditional-age 
college etudente completing the Form F inventary, $56 x$ af the melee, compared to $2 a x$ of the femeles, Indiceted a thinking preference (Myers 1 Mcceulley, 19a5). Coneldering this historicel teriency for meles to indicate thinking preferences and femeles to indicete feeling preferencen es representing traditional sacial influence, the current study's meles and the Corman-Platt females had the least traditional, ulthin-etudy, thinking (T) to feeling (F) ratiog, 1.e., wore malea in the current study than in the Carmen-Plett study expressed feeling preferences, and mare femalea in the Carman-Platt atudy then in the current study expreseed thinking preferences.

Supporting the interpretation of the TF preference es representing gender-related environmentel influence 1 s the eignificant negetive correlation $(r=-.219$ ) between age and TF preference for the current etudy's meles: the older meles tended to ecore thinking preferences and the younger meles tended to ecore feeling preferences. This inveree reletionehip of age to feeling preference could reflect a chenging eociety in which reinforcement hes ghifted from the "macho" to the "eeneitive" male. The SH/TF date are provided In Table IV.

As presented in Table $V$, the current etudy's TF ratia af 1.85 for malee 18 elgnificently leme traditianal than the Carman-Platt malee" TF ratio af 3.11 . The TF ratio af .86 for the Carmen-platt females is aleo lese traditionel than 
thet af the current etudy's fomelan and eignificently lege traditional than the . 39 TF ratio for the MBTI Data Bank'a college femeles. Thue the graupe far uhom SN and GEFT eignificently correlate--but for whow SN and TF do not elgnificantly correlate--heve mare belenced proportione of thinking and feciing preferences and therefore apper to contein more individuale expreasing TF preferenceg vhich are nontraditlonel for their gender then do the groupe for uhom no elgnificent GEFT-SN correletione vere obteinod.

The ellienco of this inferred nontreditionel fector vith the elgnificent GEFT-SN correlatione and naneignificent GX-TF correletions euggeate thet eubjecte vith atypicel SN/TF preferences demonetrated the more extreme levele of epetial reagonting ski11. The current study's meleg hed the lergent concentration of $K / T$ preferences and the cormen-plett femeleg hed en unueuel concentration of $5 / T$ preferenceg for a femele population. The equation for predicting GEFT performance for the current etudy's meles indleated a negetive TF-GEFT correletion and pleced TF ae the eecond MBTI verieble in order af importence to the prediction of MBTI-GEFT verience (See HB, p. 22). Thte ordering for the current atudy'a meles differed from the overall ardering in whtch JP wem the eecond yertable and TF vee the third.

\section{CONCLUSTON}

Beceuge of the lov etrength and reliability of the GEFT- 
SN relationehip and the ebsence of reletianehip between the GEFT and the ather MBTI dimeneione desplte their described elmilarities, this study's findinge do not readily evidence the bipoler, dichatamaus cognitive conetructe propaeed by the Witkin and the Myere-Brigge thearists. A simpler explanation painte to erreye af ekt1le acquired through expoeure and attention over time to skill-related temks, arrays uhtch vauld be, therefare, largely enviranmentelly determined and Individualietic.

This concluston facuses on the time varleble because it requires the least definttiong cen be contralled and meesured; and thus if the one element which vould be ameneble to menipulation in e gearch far a causel egent awong the reletianshipe diecuseed in these studies.

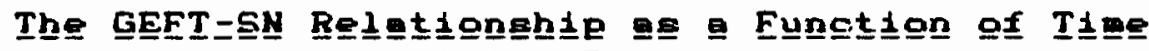

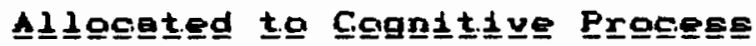

The GEFT-SN relationship may be vieved as a function of the mount of elturtianel time elloved far cognitive procens. Compared to graups who regleter an intultive (N) preferenco. sensing (S) groups have been found to demanstrate lese tolerence for ambiguity and ere more likely to terminete an amblguaus eltuatian by erriving et a quick decielon or by premature closure lChepelle \& Roberts, 1986, Myere \& MaCaulley, 1985 ).

Individuale expreseing etrong eeneing preferences may not. through unvilifngnese or Inability to allocete the 
requinite attention to cognitive praceses, be an likely to develop certain skilin--such as the spatial discrimination meenured by the GEFT--as individuala expreasing etrong intuition preferencen. High GEFT mcoren suggent e higher level of epetial procemeing then do low GEFT ecorea: therefore, the high GEFT ecorere may passeas higher-order epetial discrimination ekilie. The ensocietion of the $N$ preference with the higher ecores indlcetes the emount of time slloceted to cognitive pracese could influence the farmation of higher-order ekill. Thet higher-order cagnitive pracemsen may develop over time can be inferred from the rather ebrupt increases in learning curves, for the value of overleerning for studenta prepering for teating situetione, for the "Ahel" expertence and Prafeseor Higgine" "By George, I think she's got 1 t" It vould be at the juncture of the "Aha," alvays preceded by a certain pertad of time alloceted to the procese, that akill in in evidence. Talerance for ambiguty has aleo been found to be releted to cognitive complexity, defined an an abstract, relativiatic cagnitive etyle in contrast to the lese cepecioue, binery atyle of the lese cognitively complex (Rotter 2 0.Cannel1, 1982, P. 1218). The 1nterreletion of these three factors--talerance for ambiguity, the intuitive factor, and cognitive complexity--auggeate time allaved for cognitive procese could also engender the ecquialtion of multiple ekilie. The indiuidual vith a vide array af eleilis 
vauld engege multiple discriminetive fectore in procereing Informetion and therefore evince a mare ebetract, lese categaricel mode of cognition. Accardingly, the probability af finding a developed spatiol diecrimination ability vould be higher amang the embiguity-talerant individuele vith the larger arrays of akilis then among the ambigulty-intalerant pomenesing maller arraye of ektlle.

Also supporting the notion that larger arrays of ekt118 contribute to more abetract cognitive etyle 18 Rotter and Q'Connel1' finding thet the single most 1 mportant predictor of cognitive complexity amang study variables including SAT scores and gender vas the number of yeara of education--a c.laselc combinetion of time and skili-orlented influence (p. 1215).

Witkin eppraeched the tdee of cognitive complexity in his theary of cognitive differentiation. But. using the peremetere of his construct, fleld dependence-independence, he quelified the dimeneions of differentietion as follove:

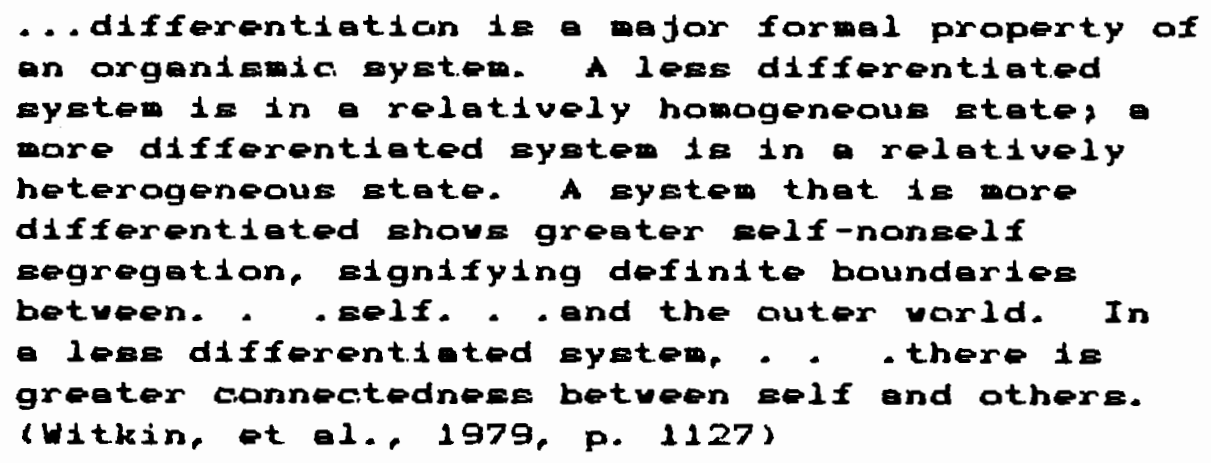

Hovever, the Rotter and Q'Connell study of sex-role and cagnitive complexity and the current study's results suggest 
thet eubjecte diepleying preferencen treditionelly ansaciated vith the apposite sex are mare cagnitively camplex then their treditianel peera. Witkin's definition did not recognize the pasaibility thet the ecquisition of en empethic akill could involye se much attention or result in es much differentietion en the acquieition of e epetiel reasoning aki11. Fram the premine that differentiation or cagnitive complexity repreaente larger rether then emeller arraye of ektlis, Individuele vho perceive "greeter connectednese betveen self and athere" cen be an argantemically differentiated ae the peraon vho mekes a greater diatinction betveen self and noneelf. The lese differentiated individuel vould be the perzon limited to anly one made of perception.

The overrepresentation of sensing and introverted types emang graupe of petiente vith diagnases of depremeion, echlzophrente, eubetence abues, and bipolar-mente disorder (B1sbere, et al. 1982) way be a function af their passessing - emeller then normel renge of ekilie. Complementing thie confecture 1 th the effectivenese of heheviaral therepy which ementisily requires the client to develop nev skills.

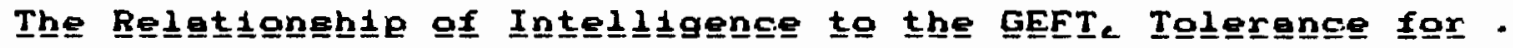

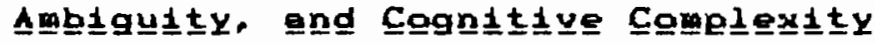

Intelligence correlates vith both GEFT performence and tolerence for ambiguity. This study's resulte indiceted the GEFT and the SN dimeneion shared little common vertance that ves not eleo related to intelligence as meesured by the 
Wonderlic Pergonnel Teat. Rotter and o'Connell. In their etudy of mex role and cognitive complexity. found the eingle most impartant predictor af tolorence for ambiguity ves the SAT verbel geare.

The predictore of cognitive complexity for femeles Included high SAT meth ecores and lov SAT verbel ecores: the predictare of cognitive complexity for meleg included lov SAT path ecares and high SAT verbel ecores (pp. $1214-1215$ ). These Inverted rolationehipe of math and verbel gcarea to cognitive complexity for beles and femelee reflect the nontreditionel direction of the gender-related TF preforenceg found emang the groups in the current and cormen-plett studies for wham SN-GEFT carrelated.

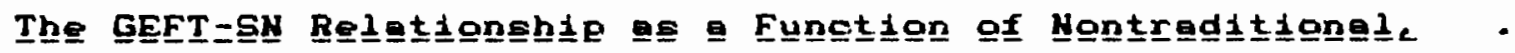
Gender $=x$ eleted Preferencese

Becauge the graupe vith algnificent GEFT-Sh carreletions demanstrated the least treditional, gender-related TF preferences, it appeare ae though the emount of time allaceted to cognitive procese may alea influence the develapment af nontraditionel preference.

Hovever, deciding what is traditional and what io not depende upon the reference group. Far exemple. the carmanPlatt eample coneleted af businese students from tuo pajor eauthuegtern univereitieg and thue provided a group of uery traditionel males--the buelnesemen, and, fram a gocial perepective, a group of nontraditianel femeles--the 
buetneesvamen. For the Carman-platt femelee, havever, the fector of leest time elloved for eltuetionel proceesing. Seneing, vas the dominant influence in career chatce.

Genertcally speaking, this group of S/T-dominated femelea may be quite traditianal but have only been eble to enter the buelnese varld as profeseionale during the latter helf af the twentieth contury.

Therefore, the euggested nontreditionel fector cen be traced to the $N$ preference which indicetes the obility or vilifngnese to allacete mare time to cognitive pracese than en $S$ preference. It way be the "mobllity-fixity" dimeneion referred to by Uitkin and found to exist for eame field Independente, but nat far athers (b1tk1n, et al., 1971, p. 11). Or, it could be en ecquired skill, perhepe eesential to creatiuity, by uhich an Individual can esenese dete nantraditionaliy or in a nev vay. Another poselbility is thet thie nontreditianel fector elmply seflecte the greeter renge of chatce evelieble to individuels who tend to acquire lerge erraye of ekil1e.

Studiee utilizing the Bew Sex Role Inventory (BSRI) elso Identify a nontraditional efex-role factor emong the variableE related ta cagnitive etyle. Ratter and a'Connell 11982, p. 1209 ) reparted,

Male and female andragynous and crase-sexed subjecte vere mare tolerent af embigulty than sex-typed eubjecte end cagnitively more complex then undifferentieted subjecte. Crase-sexed eubjecte vere mare cognitively complex then eex-typed 
eubjecte. The BSRI had differentiated power to predict cognitive camplexity depending upon cex af subject.

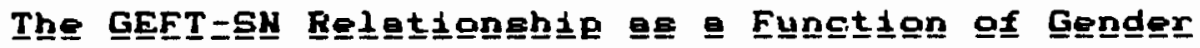

Most field dependence-independence research reporte caneiatently higher GEFT perfarmance for malea than females (Witkin, et. al., 1971); therefore, the Corman-Platt femaleg' abtaining the higher GEFT scares and the eignificant GEFT-SN carrelation was an unexpected result. The notion of a genderlese fectar beling central to cagnitive praceseing is also chellenged by neurachemicel research indiceting hormanes influence vamen's spatial reasaning. Fram a study of 200 vamen, agee 25 to 39, K1mura and Sampean (1988) cancluded that when levele af estragen and pragesterane vere lov, the vomen perfarmed better on taeke requiring spetial reasoning then they did on the mare fertile deye af their cycle uhen their eetragen and pragesterane levele vere higher. Havever. Kimure and Sempeon also noted thet these chenges in perfarmance veried drameticelly from one vamen to enother. From the perapective thet higher-arder ekilis are acquired thraugh expasure and attention over time to ekill releted teske, vamen, like men, vauld paseese varying degrees of ekili in epetiel reasoning. Those poseresing developed epatial discrimination ekilis vould find their spatial reasaning to be reletively imperviaus to changea in harmanel concentrations. For thase who do nat paseese euch ekill, the 
procese may invalue learning, rether then acceselng. and way be mare ensitive to interference of any nature.

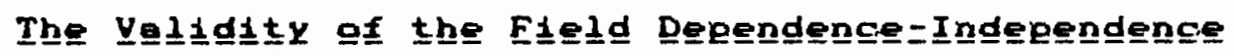

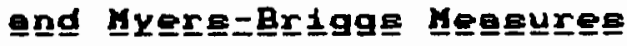

The evidence thet sensetion-seeking carreleter elgnificently vith field independence far meler, but nat far femelen, (Zuckerman, Kal1n, Price, \& Zaob, 1964) and the elgnificantly laver carrelatiane between the embedded figuree teste end the Rad and Frame Test for femeles, compared to meles, heve led meveral peychametriete to hypothenize that the emedded figuree tests are not velid meenuree of field dependency far femeles (Thartan \& Barett, 1967, LaVale, 1984). Hovever. these gender differences may eimply indicate the field dependence-independence canstruct daes not edequetely define the procene uhich it meesures eccording to its definition. The exercies appraximeter the dilemer poeed by the questian, "When did you etop beating your uife?" The embedded figures tests mey not correlete with the Rad and Freme Test (RFT) for femeles beceuse, due to enviranmental influence, it is lese likely thet femeles, compered to males, vould acquire either of these ekille, much lese bath. Far the sathe reason, eeneation seeking may not correlete uith the field independence-dependence canstruct for fomales becauge many sensetton-merking femaler way never heve ecquired the RFT ekilis out of lack of interest. reinfarcement, or opportunity. 
Intelligence carreleted eignificantly with GEFT ecares far the current etudy's weles, but nat far the current etudy's femeles. Agein, this group af femeles may not have added GEFT allile to their mare treditionel array. Similarly, the variance shared by the RFT and the GEFT might alsa be ineignificant for wales should ounership of besebell hat: be partialed out.

The MBTI 1E also problemetic. As a forced-chaice, Eelfrepart inetrument, Ite SN dimensian may elicit melf-repart preforences of eneing fram eubjecte vho do not yet poseess the cognitive skille which vould pllov them to operate canfidently in ambiguaus situations. Subjects paseeseing a larger or bipalar array of interests and skilis could expertence more eppraech-approech conflict in anevering the farced-chalce MBTI. They might chaose $S$ or $N$ responses for reesons other then the chalces mede by eubjecte vith a narraver range of cagnitive experience. Subjecte vho eflect items from apposing poles of the MBTI dimensians vith equal frequency are scared as heving lov preferences for bath poles even though their actual preferences and ability ta caperate vithin the tua cagnitive arenas may be quite etrang.

Although precurear ekille may enhence the development of other skilis, there 18 ifttle evidence that on elementary cagnitive pracess dictates the development of one set of ekille and preciludes or inhibite the formetion of on ertificieliy-defined opposite set of eltilis. Field 
dependence-1ndependence and the Myere-Brigge canetructe may be mythe.

\section{RECOMHENDATIONS}

A mete-enelysin of the etudies incorporated in this diecueston vould be velueble. Beceuse the SN-GEFT relationehipe eppear ta be lacated in the upper tall af the GEFT distributione, an enelyele of the ecores laceted in the first and third atandard devietions, omitting the middle scares, mey pravide a etranger indication af the nature of the relationehip. The farced-choice formet af the MBTI may not accurately reflect the etrength of a eubject'e propenaity to rely an both sensing and intuitive preferences, therefare, athough a poor secand chaice, carreletions af the rav $S$ and N ecares vith the GEFT should yield a mare direct indicetion of the GEFT-S and GEFT-N reletionehipe then do the difference ecores. Havever, coneidering ite forced-choice format and the increased probability of extreneous veriables influencing responses to eself-repart inventary, future research mey better profit fram posing a mare epecific question and using a more specific inetrument then tho MBTI. The adolnietretion time for the GEFT could also be shortened to increase the varience emong the GEFT ecores.

To test the assumed relatianship betveen time allacated to cagnitive pracese and cagnitive echievement, recardinge af 
time epent on various unique teske. perheps some unsolvable, could be compared to intelligence ecares, Grade Paint Averagee, or other measures of cognitive ochlevement. The lent teek could ank eubjects to recell the experimenter's inetructions for a bogus task aseignment. This exercise, ecored for accuracy, vould heve a eecondary function of providing an Indication of perceptual ekili. To test the relationehip between time allocated far cagnitive proceseing and gender-releted traditionel bohaviar, the time recardinge far the experimental teske could be compered to ecores on the Bem Sex Rale Inventary. A teek eseeseing creativity cauld also be emplayed.

For enother study, subjects demonstreting lav ettention spen could be treined to proulde langer periade of time to ambiguous et1mul1. Pre-test and post-test measures of problem solving vould be compered. A control group could be given equal, unetructured, group time.

Should the Intultive factor or time ellawed for cognitive process engender the ecquisition of multiple skills, then one could expect to find ware skills emang subjects demonstrating a high $N$ fector. An adjunct to the studies propased above wauld consist of administering a questionnelre devised to enumerate the skill-related activities and intereste far each subject and compering that number to the $N$ measure.

The value af these studies lies in their passible 
relevence to educetion. Although differences in cognitive style, learning etrategies, and the effecto of day-to-day environmentel influence on concentretion are uddely recognized, our educetional syetem continues to praceen etudente vithin a ladder of time conetreinte es thaugh the quantity and quelity of time vere uniform for each Etudent and of little consequence to the procese. If the ability to allacete time to cagnitive procese 1 e emential to learning: further research could determine if this time factor, perheps a firet couein ta intelilgence, can be learned and therefore taught. 


\section{REFERENCES}

Alper. I. (1985). Qur duel memory. In M. G. Welreven \&

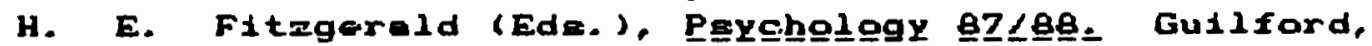
CT, The Duakin Publinhing Group.

Beer, D. I. (1964). Fectare in perception end rigidity.

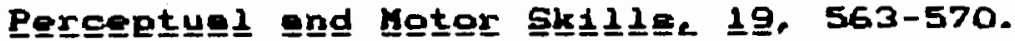

Beken, P. (1969). Hypnotizability, leterelity af eye movemente and functionel brain aeymmetry. Percentuel

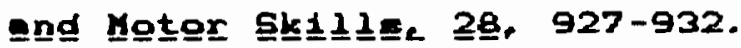

Baken, P., \& Shatlend, R. (1969). Leterel eye movement, reading speed and vieunl attention. Peychongete Sectencee 15. 93-94.

Bleber, C., Mullaly, R., \& Gemond, H. (1982). Type and

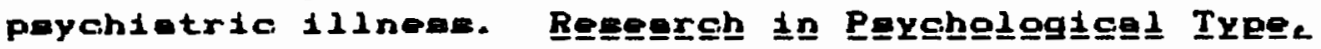
5. 49-68.

Brooks, F. R., L Johnson, R. W. (1979). Self-demcriptive edjectiven neecalated vith e Jungien pereanelity inventory. Peychelog

Carleon, I. (1985). Recent mesememente of the Myere-Briggr Type Indicetor. Igurnel of Peregnelity Aseesesemente 49 . 356-365.

Carlean, R. (1980). Studies of Jungtan typology, II. Representatione of the personel vorld. Iournel of

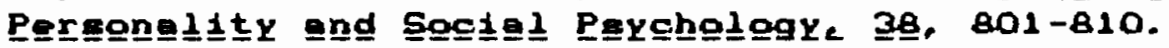

Cerlyn, K. (1977). An ameenement of the Myere-Brigge Type

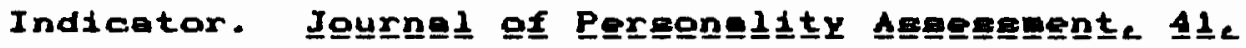
$461-473$.

Cermekdon, T. G., \& Knudson, M. L. (1978). Reletionshipe betveren conceptuel eyeteme end peycholagiciel typee. Peychologicel Regortél 42. 483-4B6.

Chepelle, C., \& Roberta, C. (1986). Ambiguity talerence and field independence as predictore of efficiency in Englifh en eccond lenguage. Lenguege Leerninge 36 . 27-45. 
Cleeye, W., DeBoeck, R., I Vieene, M. (1976). Fiflddependence end stability of melf-view. Pergeptugl end

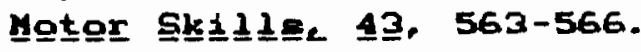

Cormen, L. S., \& Plett, R. G. (198A). Correletione enong the Group Embedded Figures Test, The Myere-Brigge Type Indicetor and denographic cherecteristices a businese

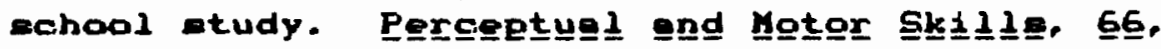
$507-511$.

Crondell, v. C., \& Lecey, B. W. (1972). Children'= perceptione of internel-externel control in Inteliectuel-acedentc altuetione end their embedded figuree teat performence. ChIld Developegnte 43 . 1123-1134.

Dengerink, H. A., D'Leary, H. R., \& Kanner, K. H. (1975). Individual differencen in eggremeive remponees to etteck, internal-externel locue of contral and field dependence-independence. Journel of Regeerch ín Pereonelitye $9.191-199$.

Devinne, R., \& Johneon, R. W. (1976). ExtreveraionIntroveralons the permonelity cherecterietlce of drug

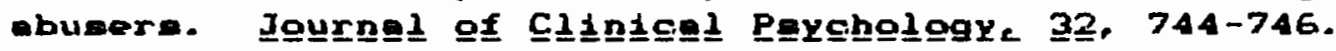

Dewitt, G. W., A Avertil, F. R. (1976). Loteral oye eqvemente. hypnotic musceptibility and field

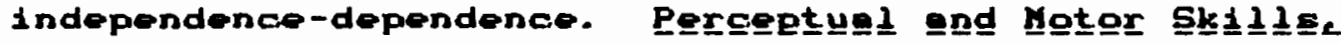
43. 1179-1184.

Eliat, I., \& Herdy, R. C. (1977). Internelity and extreversion-introveraion. Perceptuel end Motor

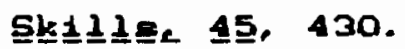

El110t, R. (1961). Interreletionshipe emong moneures of field dependence, ability, and permonality treite.

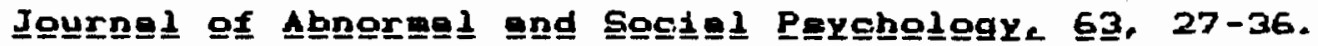

Goldemith, R. E. (1985). Senzetion meeking and the senaingintuition ecele of the Myere-Brigge Type Indicator. PExchologicol Reporties 56, $581-582$.

Goodenough, D. (1986). Hietory of the field dependence conetruct. In M. Bertini, L. Pizzeniglie a S. Wagner (Eda.). Eíld negendence ín Peychological Theorye

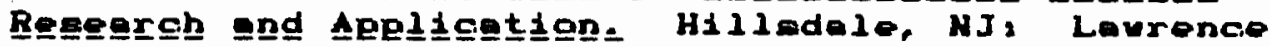
Erlbaue Ameacieter. 
Gruenfeld, L. W., Arbuthnot, I. (1968). Fifld dependence, chievewent velues end the eveluetion af a competency related dimeneion on the leest preferred co-vorker

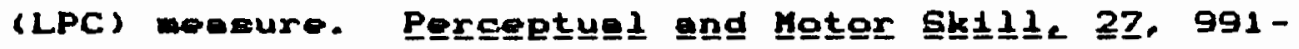
1002.

Gur, R., Gur, R., \& Herria, L. J. (1975). Cerebrel nctivetion en weneured by eubjecte' leterel eye movementa 1 influenced by experimenter lacetion.

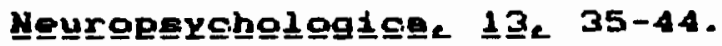

Iecobean, G. R., Ven Dyke, A., Sternbech, T. G., \& Bretheuer, R. (1976). Field dependence emong mele end female elcoholicin. II. Norme for the Rad-end-Freme teret.

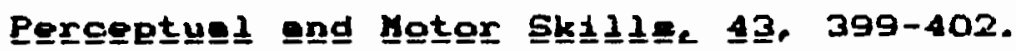

Jung, C. G. (1971). Peychologicel Typee (H. G. Beynee, Trens. revised by R. F. C. Hulll. Volume 6 of The

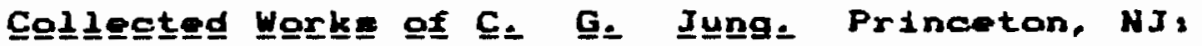
Princeton Univereity Prese. (Originel work publibhed in 1921.)

Kelly, E. J. (19a5). The personelity of chemspleyera.

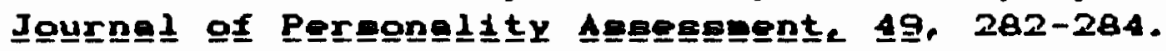

K11lean, R. H., \& Thomee, K. H. (1975). Interpereonel conflict-handling behevior as reflective of Jungian permanelity dimeneians. Peychologicel Regortse 3 . $971-980$.

K1=ure, D., \& Sempeon, E. (1989). (Effecte af estrogen end progenterone levele on epeciel reseoningl. Unpubliehed rev dete. Univereity of Hestern Onteria.

Kociel, K., Gelin, D., Ornetein, R., Merrin, E. (1972). Leterel eye movement and cognttluo made. Peychongeis Sciensene 27. 223-224.

Lavaie. A. (1984). Embedded Figuren Teet. In D. J. Keyeer \&

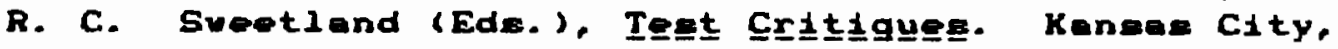
MO, Westport Publishors, Inc.

Loo, R. (1979). The need to report distribution cherecteriatice of ecores on field-dependence meseures.

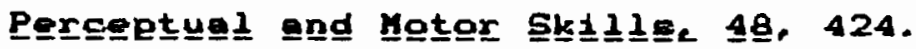

Lovelese, E. J. (1972). Cagnitive etyles, orienting reeponees and eelf-repart meneuren of personelity.

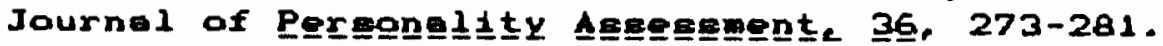


Lusk, E. J., \& Wright, H. (1983). Reletion of ecoren on Group Embedded Figuree Teat and Myers-Brigge Type

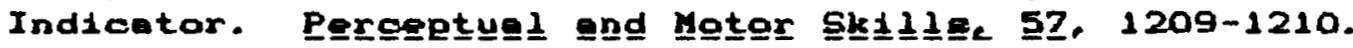

Matthevs, S. K., Milier, D. I., I Carakedon, T. G. (1981). Conformity behevior in an experimentel attuetion en. function of peychologicel type. Regeerch 1 n Peychologices Typet $4,62-70$.

Mendeleohn, G. (1965). The Myers-Brigge Type Indicator. In

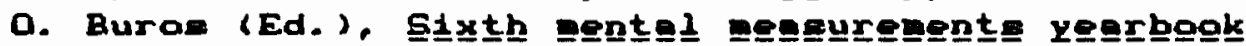
(pp 321-322), Highland Park. NJ2 Gryphon Prees.

Muawuenda, T. S., Dionne, J. P., L Mvenvende, B. B. (1985). Theoreticel and enpiricel link between peychological differentiation and extravereian. Peycholggicel Reporte르 56, 147-154.

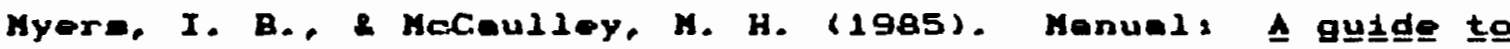
the develogegnt end use gx the Hyers=Brigge Tyee Indigentor. Palo Alto, CAI Coneulting Peychologiete Premen.

Oltmen, R. K., Goadenough, N. R., Wltkin, H, A., Freedmen, N., \& Friedmen, F. (1975). Paycholagical differentiation a a fector in conflict resolution.

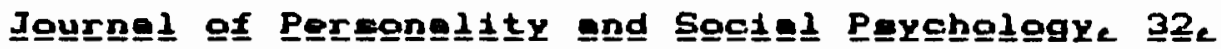
$730-736$.

Pebibertion, C. L. (1952). The cilosure fectore related to temporement. Iournel of Pergenelttye 21. 159-175.

Robinfon, D. L. (1983). Structure of Witkin' embedded

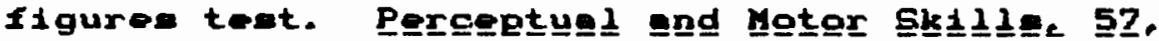
$119-125$.

Rotter, H. G., \& Q'Connel1, A. H. (1982). The relatianehipe - mang eex-rale ortentetion, cognitive complexity, and tolerence for embiguity. Sex Rolese. ‥ 1209-1220.

Saume-Pare, J. R., Rohrberg, R., \& Shulmen, E. (1973). Field dependence end eelf-dimaloeure. Perceptuel end Hoter

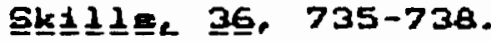

Sauge-Poze, J. R., \& Rohrberg, R. (1976). Communtantianel and Interectionel empecte of melf-dimclomure in peychotherapy. Differences releted to cognitive etyle. Peychieterye $39,81-91$.

Sperry, R. (1982). Same effects af diecannecting the cerebral homiepheres. Sciences 21Z, 1223-1226. 
Thorton, C. L.. I Berrett, G. V. (19G7). Hethodolagicel note on $N$ achlevement and fleld Independence comparimone.

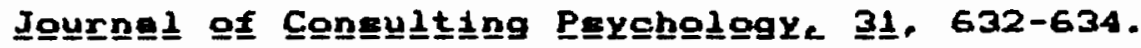

Wechte1, P. L. (1972). Fleld dependence and peychologicel differentiotions Reexeminetion. Perceptuel end Hotor Sk1ㅣ를. 3․․ 179-189.

Weetbraok. M. (1974). Judgment of emotions Attention vereug

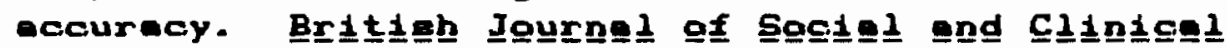
PEYcholggye 13, 383-389.

W11118, E. (1984). Myere-Rrigge Type Indicetor. In D. J. Keymer \& R. C. Sweetlend (Ede.). Test Crittiquese. Kenees City, MO, Westpart Publishers, Ino.

Witkin, H. A., Dyk, R. B., Fettermon, H. F., Gaodenough, D., - Kerp. S. A. (1962). Psychglogicel diftierention. Nev Yorke Wiley.

Witkin, H. A., \& Goodenough, D. R. (1977). Field dependence

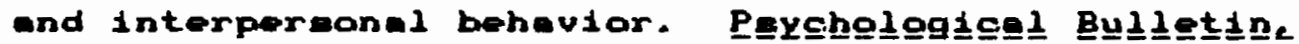
요. $661-689$.

Witkin, H. A., Moore, C. A., Goodenough, D. R., 2 Cax, P. W. (1977). Field-dependent end field-independent cognitive mtylem and thelr educationel implicatione. Reviev af Educetionel Remerch, 47, 1-64.

Witkin, H. A., Oltwan, P. K., Reskin, E., I Kerp, S. A. (1971). A ㅂenuel for the Embedded Elgures Testes. Palo Alto, CAl Consulting Prychologilet Prose, Inc.

2igler. E. (1963). A woenre in merch of a theory? Contereporery Perychololggye o. 133-135.

Zuckerman, M., Kalin, A., Price, L., L Zaob, I. (1964). Developient af enenetion-eeking ecele. Iournel of

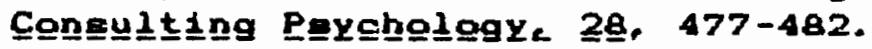

Zuckerwen, M.. \& Link, K. (1968). Construct velidity for the

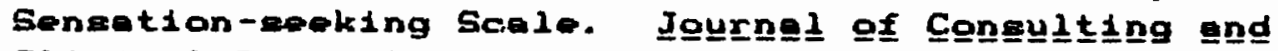

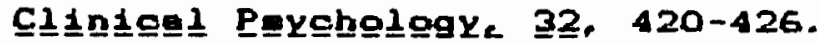




\begin{abstract}
APPENDIX A
SAMPLE MEANS AND STANDARD DEVIATIONS FOR GEFT, MBTI, INTELLIGENCE AND AGE FOR THE CURRENT STURY BY GENDER
\end{abstract}

Ald Subjecte y 프

$(\underline{A}=202)$
Feneleg

$\underline{\underline{S} \underline{\underline{n}}}$

$\ln =108)$
Malea

I Sn

$(\underline{n}=94)$

\title{
GEFT \\ MBTI 2
}

11.85

4.60

11.47

4. 50

12.28

4.70

$\begin{array}{lllllll}\text { EI } & 100.18 & 27.32 & 98.15 & 27.66 & 102.51 & 26.87 \\ \text { SN } & 100.55 & 27.15 & 99.56 & 25.95 & 101.68 & 28.57 \\ \text { TF } & 97.95 & 21.80 & 104.96 & 19.90 & 89.89 & 21.20 \\ \text { IP } & 100.80 & 27.36 & 97.68 & 25.63 & 104.38 & 28.95\end{array}$

Age

$$
\begin{array}{cc}
24.29 & 7.02 \\
\ln & =1011
\end{array}
$$

25. 39

8. 41

23. 03

4.70

$(\underline{n}=52)$

$(n=48)$

Intelligence

23.69

6. 18

22.77

5. 34

24.67

6.88 


\begin{abstract}
APPENDIX B
POLAR DISTRIBUTION OF CURRENT STUDY'S SCORES

FOR THE MBTI SCALES AND THE GEFT

BY GENDER
\end{abstract}

Clemelficetion

$\mathbf{E}$

$\mathbf{I}$

$\mathbf{5}$

$\boldsymbol{N}$

$\mathbf{T}$

$\mathbf{F}$

J

$\mathbf{P}$

\section{GEFT}

$y=11.85$

$$
\text { Melem }
$$

$$
\text { n }=94
$$

44

50

44

50

61

33

40

54

53

41
Fenelem

n $=108$

59

49

57

51

44

64

62

46
Above $\mathrm{I}$

Belov $\mathrm{x}$
49

59
105

97

102

100

Tatel

$\underline{4}=202$

103

99

101

101

105

102

100 
APPENDIX C

PERCENTAGE DISTRIBUTIONS OF SUBJECTS AMONG MBTI TYPE CLASSIFICATIONS, CURRENT STUDY AND MBTI DATA BANK

\section{Fondeg}

Neles

$$
\begin{array}{r}
\text { Current Study } \\
n=94
\end{array}
$$

EST J

$10.64 x$

8. $51 x$

3. $19 x$

3. $19 x$

5. $32 x$

2. $13 x$

9. $57 x$

$4.26 x$

11. $70 x$

4. $26 x$

$9.57 x$

6. $38 x$

3. $19 x$

3. $19 x$

7. $45 x$

7. $45 x$

ISTP

$$
\begin{aligned}
& \text { Det. Bank: } \\
& \underline{n}=5,632
\end{aligned}
$$

$11.24 x$

6. $46 x$

6. $59 x$

5. $40 x$

5. $38 x$

$3.69 x$

6. $16 x$

7. $48 x$

5. $84 x$

2. $93 x$

5. $81 x$

4. $31 x$

6. $27 x$

5. $10 x$

10. $60 x$

$6.75 x$
Dete Benk

$n=108 \quad n=9,616$

$11.76 x \quad 7.53 x$

1. $85 x$

2. $56 x$

B. $33 x$

16. $20 x$

6. $48 x$

B. $54 x$

5. $56 x$

2. $85 x$

$7.41 x$

6. $B B X$

5. $56 x$

$3.06 x$

B. $33 x$

12. $32 x$

9. $26 x$

5. $7 B x$

4. $66 x$

3. $81 x$

4. $63 x$

1. $94 x$

1. $85 x$

1. $90 x$

10. $19 x$

12. $26 x$

4. $63 x$

6. $14 x$

B. $33 x$

6. $01 x$

Hyera and McCoulley, 1985 PP. 46-48,

1. $85 x$

2. $22 x$ 